\title{
Seasonal dynamics of the depth and rate of anaerobic oxidation of methane in Aarhus Bay (Denmark) sediments
}

\author{
by A. W. Dale ${ }^{1,2}$, D. R. Aguilera ${ }^{1}$, P. Regnier ${ }^{1}$, H. Fossing ${ }^{3}$, \\ N. J. Knab ${ }^{4}$ and B. B. Jørgensen ${ }^{4,5}$
}

\begin{abstract}
A reactive-transport model has been applied to investigate the dynamics of the sulfate-methane transition zone (SMTZ) in nearshore sediments of Aarhus Bay (Denmark). The sediments are influenced by seasonal variations of temperature and particulate organic carbon (POC) deposition flux at the sediment-water interface. Initially, the model was calibrated at steady state using field data collected at two sites (M1 and M5) in December 2004, and included a dynamic gas phase which determines the depth of the SMTZ. Simulations were then performed under transient conditions of heat propagation in the porous medium, which influenced the solubility of gaseous methane, the diffusion of solutes as well as the kinetic and bioenergetic constraints on redox conditions in the system. Results revealed important variations in local rates of anaerobic oxidation of methane (AOM) over a seasonal cycle due to temperature variation. Seasonal perturbations in POC depositional flux had no influence on AOM rates but did have a strong bearing on sulfate reduction rates in the surface layers of the simulations at both stations. At M5, where the SMTZ was located $63 \mathrm{~cm}$ below the sediment-water interface, depth integrated AOM rates varied between 76 and $178 \mathrm{nmol} \mathrm{cm}^{-2} \mathrm{~d}^{-1}$. At M1, where the deeper SMTZ (221 cm) experienced less thermal variation, AOM rates varied relatively less (20 to $24 \mathrm{nmol} \mathrm{cm}^{-2} \mathrm{~d}^{-1}$ ). Furthermore, local and depth-integrated AOM rates over the year did not show a simple response to bottom water temperature but exhibited a hysteresis-type behavior related to time lags in solute transport and heat propagation. Overall, the solute concentration profiles were not very sensitive to the seasonal variability in rates or gas transport and the modeled vertical displacement of the SMTZ was limited to $<1 \mathrm{~cm}$ at M1 and $2-3 \mathrm{~cm}$ at M5. The results suggest that the significantly larger apparent displacement observed in the field from repeated coring ( $80 \mathrm{~cm}$ and $16 \mathrm{~cm}$ at M1 and M5, respectively) must be attributed to other factors, of which spatial heterogeneity in gas transport rate appears to be the most likely.
\end{abstract}

1. Department of Earth Sciences - Geochemistry, Utrecht University, P. O. Box 80021, 3508 TA Utrecht, Netherlands.

2. Corresponding author.email: dale@geo.uu.nl

3. National Environmental Research Institute, Department of Marine Ecology, Vejlsøvej 25, 8600 Silkeborg, Denmark.

4. MPI for Marine Microbiology, Celsiusstr. 1, D-18359 Bremen, Germany.

5. Center for Geomicrobiology, University of Aarhus, Ny Munkegade, Bldg. 1540, DK-8000 Århus C, Denmark 


\section{Introduction}

Several detailed experimental studies have shown that organic matter mineralization rates and microbial activity in both nearshore (e.g. Westrich and Berner, 1988; Klump and Martens, 1989) and deep-sea sedimentary environments (e.g. Soetaert et al., 1996; Moodley et al., 2005) can be influenced by seasonal changes in temperature and/or particulate organic carbon (POC) flux to the sea floor. Such seasonal variability at the sediment-water interface leads to concentration gradients of the primary oxidants of POC mineralization (e.g. $\mathrm{O}_{2}, \mathrm{NO}_{3}^{-}, \mathrm{Mn}(\mathrm{IV}), \mathrm{Fe}(\mathrm{III}), \mathrm{SO}_{4}^{2-}$ ) which are not constant with time (Crill and Martens, 1987; Glud et al., 2003; Koretsky et al., 2005; Treude et al., 2005). The magnitude of this seasonal oscillation depends on the relative size of the perturbation at the system boundaries, the rates of transport and reaction and, thus, on the quality of the substrate (Treude et al., 2005; Burdige, 2006). Additional complexities can be introduced by the substrate uptake response to temperature, which is not necessarily the same for the entire microbial community (Weston and Joye, 2005). Consequently, modeling approaches have proved useful to elucidate the seasonal variability observed in the redox biogeochemistry of sediments (Klump and Martens, 1989; Alperin et al., 1994).

Aarhus Bay is a shallow embayment on the eastern Danish coast characterized by a relatively small, yet notable, seasonal change in the sediment depth distribution of oxidized and reduced metabolites (e.g. $\mathrm{Fe}^{2+}, \mathrm{NH}_{4}^{+}, \mathrm{H}_{2} \mathrm{~S}$ ) (Thamdrup et al., 1994; Fossing et al., 2004). The quantitative significance of these seasonal changes for the sulfate reducing and methanogenic zones has not yet been addressed, although investigations elsewhere have revealed seasonal variability resulting from significant changes in redox rates directly or indirectly coupled to organic matter decomposition (Crill and Martens, 1987; Klump and Martens, 1989). Sediment cores collected in Aarhus Bay and analyzed during the METROL project (www.metrol.org) revealed that the subsurface sediments are methanerich, with a well-defined sulfate-methane transition zone (SMTZ), where sulfate and methane simultaneously coexist. In this SMTZ, methane is oxidized anaerobically by microorganisms using sulfate as the terminal electron acceptor (Hoehler et al., 1994; Boetius et al., 2000). Although anaerobic oxidation of methane (AOM) is a sluggish process, it constitutes a globally effective sink against methane escape from marine sediments to the ocean and atmosphere (Reeburgh, 1996). AOM is particularly relevant in the sediments of Aarhus Bay because super-saturation of the pore water leads to the formation of methane bubbles which are detectable by ship-board seismic-acoustic profiling techniques (Laier and Jensen, 2007). An investigation into the dynamics of methane and AOM over a seasonal cycle in an organic-rich nearshore environment, such as Aarhus Bay, will thus provide additional constraints on the environmental factors regulating the efficiency of the subsurface methane barrier.

In this study, a reaction-transport model (RTM) is applied to data from Aarhus Bay sediments to investigate the role of seasonal bottom water temperature on substrate turnover rates, with particular reference to sulfate reduction coupled to AOM and the SMTZ depth. For the sake of completeness, the variability in POC depositional flux is also 
considered. To help identify the effect of seasonal changes in bottom water temperature, the heat equation is solved to simulate the spatial and temporal evolution of temperature in the sediment. This variable influences the biogeochemical reaction rates, the rate of solute diffusion and the solubility of methane. The reaction network employed is similar to that developed by Dale et al. (2008) for sediments from a similar depositional environment in the Skagerrak, and focuses on sulfate reduction and methanogenesis which are ultimately driven by hydrolysis and fermentation of POC deposited at the sediment surface. However, in addition to the transient effects, the present model includes an explicit representation of the gaseous methane phase. The gas concentration is dependent on the in situ methane solubility, the rate of gas transport through the sediment and ebullition and dissolution. The model elucidates the quantitative role of temperature on the spatial and temporal distribution of constituent concentrations and microbial reaction rates in the anoxic sediments of Aarhus Bay.

\section{Material and methods}

\section{a. Site description and data acquisition}

Aarhus Bay is a shallow semi-enclosed embayment situated on the transition between the North Sea and Baltic Sea, characterized by elevated primary production from spring to fall (Glud et al., 2003). The sediments in the bay are 6-7 m thick Holocene mud deposits ( $\sim 10$ ky BP, Jensen and Laier, 2003) which overlie brackish, late glacial clay-silt and till (Laier and Jensen, 2007). Free methane gas in the sediment is widespread where the mud thickness exceeds 4-5 m, and the upper boundary of gas below the sea floor varies from $50 \mathrm{~cm}$ to $400 \mathrm{~cm}$ depth (Laier and Jensen, 2007).

Samples were collected during METROL (www.metrol.org) research cruises in Aarhus Bay, Denmark, on four occasions between March 2003 and December 2004. Two stations were visited: Station M1 located at position $56^{\circ} 07^{\prime} 07 \mathrm{~N}, 10^{\circ} 20^{\prime} 79 \mathrm{E}$ (15 m water depth) and Station M5 at $56^{\circ} 06^{\prime} 20 \mathrm{~N}, 10^{\circ} 27^{\prime} 47 \mathrm{E}$ ( $\sim 27 \mathrm{~m}$ water depth). This study presents data from December 2004 (bottom water temperature $281 \mathrm{~K}$ ) which exemplify the main geochemical characteristics of the system. Weekly time series data during 2004 revealed that bottom water salinity undergoes a variation of $27 \pm 2$ with no seasonal pattern (data not shown). Groundwater seepage was not observed at the study sites.

Gravity cores of $\sim 3 \mathrm{~m}$ length were collected and sectioned in $10 \mathrm{~cm}$ depth intervals for biogeochemical analyses. Part of the surface sediment was lost during gravity coring and the upper $50 \mathrm{~cm}$ of undisturbed surface sediment was in addition sampled with a smaller 'RumoHr Lot' coring device. The sulfate $\left(\mathrm{SO}_{4}^{2-}\right)$ concentration profiles measured in the two sediment cores were superimposed and the loss of sediment was calculated with a $\pm 3 \mathrm{~cm}$ uncertainty in the thickness of sediment lost during gravity coring. The data in this study are plotted using this corrected composite depth.

Methane $\left(\mathrm{CH}_{4}\right)$ concentration was determined in a sediment sample of $3 \mathrm{~cm}^{3}$. The sediment was sampled immediately after retrieval of the sediment core and transferred to a 
$20 \mathrm{ml}$ serum vial with $6 \mathrm{ml}$ demineralized water, capped with a butyl rubber stopper, crimp-capped and vigorously shaken. After gas equilibration, the headspace was analyzed on a gas chromatograph (5890A, Hewlett Packard) equipped with a packed stainless steel Porapak-Q column (6 ft., 0.125 in., 80/100 mesh, Agilent Technology) and a flame ionization detector. Helium was used as a carrier gas at a flow rate of $30 \mathrm{ml} \mathrm{min}^{-1}$ and the $\mathrm{CH}_{4}$ peak appeared 0.65 minutes after injection of the headspace gas. The area of the $\mathrm{CH}_{4}$-peak was calculated with an integrator (Hewlett Packard 3395).

Particulate organic carbon (POC) was determined on approximately $100 \mathrm{mg}$ of dried sediment acidified with 1-2 drops of $\mathrm{H}_{2} \mathrm{SO}_{4}$ to degas carbonates as $\mathrm{CO}_{2}$. The acid-washed sample was then combusted in a CHN-analyzer (Roboprep CN, Europe Scientific, UK) during which POC was transferred to $\mathrm{CO}_{2}$ and measured by TCD-detection. The POC content was calculated in $\mathrm{mg} \mathrm{C}$ and expressed as percent dry sediment weight.

Dissolved inorganic carbon (DIC) concentrations were measured by flow injection (Hall and Aller, 1992) on headspace-free sealed pore water samples stored at $10^{\circ} \mathrm{C}$. The samples were injected into a continuous flow of $\mathrm{HCl}$ solution $(30 \mathrm{mM})$ and the $\mathrm{CO}_{2}$ diffused across a Teflon membrane into $\mathrm{NaOH}(10 \mathrm{mM})$ and measured by a conductivity detector (VWR scientific, model 1054).

The $\mathrm{SO}_{4}^{2-}$ concentration was measured in pore water squeezed from $\sim 20 \mathrm{~cm}^{3}$ sediment with $\mathrm{N}_{2}$ through a $0.45 \mu \mathrm{m}$ cellulose acetate filter. Pore water was collected into a $5 \mathrm{ml}$ glass syringe and $1 \mathrm{ml}$ was preserved $0.25 \mathrm{ml} \mathrm{ZnCl}_{2}(2 \% \mathrm{w} / \mathrm{v})$ for subsequent sulfate concentration measurement. Depending on the sulfate concentration, the $\mathrm{ZnCl}_{2}$ preserved pore water sample was diluted up to 100 fold and filtered $(0.45 \mu \mathrm{m})$ before measurement. Concentration determination was done by non-suppressed anion exchange chromatography (Waters 510 HPLC Pump; Waters IC-Pak 50 x $4.6 \mathrm{~mm}$ anion exchange column; Waters 430 Conductivity detector) with an isophthalic acid eluant $(1 \mathrm{mM}, \mathrm{pH} 4.7$, in methanol, $10 \% \mathrm{v} / \mathrm{v})$.

Sulfate reduction (SR) rates were determined by the ${ }^{35} \mathrm{SO}_{4}^{2-}$ tracer method in $10 \mathrm{~cm}$ long sub-cores (26 mm ID) (Jørgensen, 1978) sampled directly from the gravity core. Immediately after sub-sampling, $\sim 10 \mu \mathrm{l}\left(400 \mathrm{kBq}\right.$ ) carrier-free ${ }^{35} \mathrm{SO}_{4}^{2-}$ (Ris $\varnothing$ Isotope Laboratory, Denmark) was injected horizontally, at $1 \mathrm{~cm}$ intervals, into the sediment through siliconestoppered ports. The radio-labeled sub-cores were incubated for $8-16$ hours at in situ temperature in the dark and terminated by preserving $2 \mathrm{~cm}$ sediment sections in $20 \% \mathrm{ZnAc}$ (v:v). The preserved sediment was vigorously shaken and frozen until distillation and determination of ${ }^{35} \mathrm{SO}_{4}^{2-}$ and ${ }^{35} \mathrm{~S}$ (in Chromium Reducible Sulfur, CRS, i.e. $\mathrm{H}_{2}{ }^{35} \mathrm{~S}+\mathrm{Fe}^{35} \mathrm{~S}+{ }^{35} \mathrm{~S}^{\mathrm{o}}+\mathrm{Fe}^{35} \mathrm{~S}_{2}$ ) following the technique of Fossing and Jørgensen (1989). The SR rate was calculated from the fraction of reduced sulfur produced:

$$
\mathrm{SR}=\frac{\zeta-\xi}{\eta+\zeta}\left[\mathrm{SO}_{4}^{2-}\right] \frac{24}{t_{\text {inc }}} 1.06 \mathrm{nnol} \mathrm{cm} \mathrm{cd}^{-3} \mathrm{~d}^{-1}
$$

where $\zeta$ is the radioactivity of the reduced ${ }^{35} \mathrm{~S}$ per volume sediment, $\xi$ is the radioactivity of a blank sample (i.e. the carry over of ${ }^{35} \mathrm{SO}_{4}^{2-}$ analyzed as reduced ${ }^{35} \mathrm{~S}$ (Fossing et al., 2000)), 
$\eta$ is the radioactivity of the sulfate per sediment volume after incubation, $\left[\mathrm{SO}_{4}{ }^{2-}\right]$ is the sulfate concentration $\left.(\mathrm{nmol} \mathrm{cm})^{-3}\right), t_{i n c}$ is the incubation time in hours, and 1.06 is an estimated isotopic fractionation factor.

\section{b. Model set-up}

i. Coupled transport and reaction. The model approach for M1 and M5 was divided into two parts (i) a steady state baseline simulation consisting of the model calibration to the December 2004 data, and (ii) transient simulations to investigate the physical and geomicrobial response to seasonal forcing at the sediment surface. The reaction network implemented was similar to the one used by Dale et al. (2008) for modeling anaerobic diagenesis in Skagerrak sediments. The model simulated the $700 \mathrm{~cm}$ of Holocene mud present at $\mathrm{M} 1$ and $\mathrm{M} 5$, and included six dissolved species (sulfate $\left(\mathrm{SO}_{4(\mathrm{aq})}^{2-}\right)$, methane $\left(\mathrm{CH}_{4(\mathrm{aq})}\right)$, hydrogen $\left(\mathrm{H}_{2(\mathrm{aq})}\right)$, acetate $\left(\mathrm{CH}_{3} \mathrm{COO}_{(\mathrm{aq})}^{-}\right.$, termed Ac hereafter), dissolved inorganic carbon (DIC), low molecular weight dissolved organic carbon (LMW-DOC), and three types of solid POC species; a labile $\left(\mathrm{POC}_{\mathrm{LAB}}\right)$ and refractory fraction $\left(\mathrm{POC}_{\mathrm{REF}}\right)$ and a fraction of intermediate reactivity $\left(\mathrm{POC}_{\mathrm{MID}}\right.$ ) for $\mathrm{M} 5$ only. One gaseous species (methane gas, $\mathrm{CH}_{4(\mathrm{~g})}$ ) was also considered. Tables 1 and 2 present the reaction network and the corresponding rate parameters, respectively.

The one-dimensional scalar mass-conservation equation (e.g. Berner, 1980; Boudreau, 1997) was used to resolve the depth profiles of solutes (Eq. 2a), solids (Eq. 2b) and $\mathrm{CH}_{4(\mathrm{~g})}$ (Eq. 2c):

$$
\begin{gathered}
\varphi \frac{\partial \mathrm{C}_{\mathrm{S}}}{\partial t}=\frac{\partial}{\partial x}\left(\varphi\left(D_{S}+D_{b}\right) \frac{\partial \mathrm{C}_{\mathrm{S}}}{\partial x}\right)-\frac{\partial\left(\varphi v \mathrm{C}_{\mathrm{S}}\right)}{\partial x}+\varphi \alpha\left(\mathrm{C}_{\mathrm{S}, 0}-\mathrm{C}_{\mathrm{S}}\right)+\varphi \mathrm{R} \\
(1-\varphi) \frac{\partial \mathrm{C}_{\mathrm{P}}}{\partial t}=\frac{\partial}{\partial x}\left((1-\varphi) D_{b} \frac{\partial \mathrm{C}_{\mathrm{P}}}{\partial x}\right)-\frac{\partial\left((1-\varphi) v \mathrm{C}_{\mathrm{P}}\right)}{\partial x}+(1-\varphi) R \\
\varphi \frac{\partial \mathrm{CH}_{4(\mathrm{~g})}}{\partial t}=\frac{\partial}{\partial x}\left(\varphi\left(D_{C H 4(g)}+D_{b}\right) \frac{\partial \mathrm{CH}_{4(\mathrm{~g})}}{\partial x}\right)-\frac{\partial\left(\varphi v \mathrm{CH}_{4(\mathrm{~g})}\right)}{\partial x}+\varphi \alpha\left(\mathrm{CH}_{4(\mathrm{~g}), 0}-\mathrm{CH}_{4(\mathrm{~g})}\right)+\varphi R
\end{gathered}
$$

where $x(\mathrm{~cm})$ is the vertical depth, $t(\mathrm{y})$ is time, $\varphi\left(\mathrm{L}\right.$ pore water $\left.(\mathrm{L} \text { wet sediment })^{-1}\right)$ is the depth-dependent porosity, $\mathrm{C}_{\mathrm{S}}\left(\mathrm{mol} \mathrm{L}^{-1}\right)$ and $\mathrm{C}_{\mathrm{P}}\left(\mathrm{mol} \mathrm{g}^{-1}\right)$ are the time-dependent concentrations of solutes and solids, respectively, $\mathrm{C}_{\mathrm{S}, 0}\left(\mathrm{~mol} \mathrm{~L}^{-1}\right)$ and $\mathrm{CH}_{4(\mathrm{~g}), 0}\left(\mathrm{~mol} \mathrm{~L}^{-1}\right)$ are the solute and $\mathrm{CH}_{4(\mathrm{~g})}$ concentration at the top of the core, $D_{S}\left(\mathrm{~cm}^{2} \mathrm{y}^{-1}\right)$ is the tortuositycorrected molecular diffusion coefficient, $D_{b}\left(\mathrm{~cm}^{2} \mathrm{y}^{-1}\right)$ is the bioturbation coefficient, $v\left(\mathrm{~cm} \mathrm{y}^{-1}\right)$ is the sediment accumulation rate, $\alpha\left(\mathrm{y}^{-1}\right)$ is the bioirrigation coefficient and $R$ is the sum of the rate of concentration change due to reactions. Further details of the depth dependency of $D_{b}$ and $\alpha$ are summarized in Table 3 .

$\mathrm{CH}_{4(\mathrm{~g})}$ was transported through the sediment using an apparent diffusion coefficient, $D_{C H 4(g)}$ (Table 3). This was used as a model fit parameter for the depth of the SMTZ since 
Table 1. Reaction network and depth-integrated turnover rates $\left(\mathrm{nmol} \mathrm{cm} \mathrm{cm}^{-2} \mathrm{~d}^{-1}\right)$ of the substrates (in bold) for the steady-state baseline simulations (upper, in bold italic) and the seasonal range (below) rounded to the nearest integer. Reactions are written for the transfer of 1 mole of electrons, where DIC, POC and LMW-DOC are defined as bicarbonate ion $\left(\mathrm{HCO}_{3(\mathrm{aq})}^{-}\right)$carbohydrate $\left(\mathrm{CH}_{2} \mathrm{O}_{(\mathrm{s})}\right)$ and glucose $\left(\mathrm{C}_{6} \mathrm{H}_{12} \mathrm{O}_{6(\mathrm{aq})}\right)$, respectively, for mass balance and Gibbs energy calculations.

Reaction

$R_{1}$ HYdRolysis of $\Sigma$ POC to LMW-DOC

$$
\mathrm{CH}_{2} \mathbf{O}_{(\mathrm{s})} \rightarrow 1 / 6 \mathrm{C}_{6} \mathrm{H}_{12} \mathrm{O}_{6(\mathrm{aq})}
$$

$R_{2}$ Fermentation of LMW-DOC

$1 / 24 \mathbf{C}_{6} \mathbf{H}_{12} \mathbf{O}_{6(\text { aq })}+1 / 6 \mathrm{H}_{2} \mathrm{O}_{(1)} \rightarrow 1 / 12 \mathrm{CH}_{3} \mathrm{COO}_{(\mathrm{aq})}^{-}+$ $1 / 6 \mathrm{H}_{2(\mathrm{aq})}+1 / 6 \mathrm{H}_{(\mathrm{aq})}^{+}+1 / 12 \mathrm{HCO}_{3(\mathrm{aq})}^{-}$

$R_{3}$ Sulfate Reduction with $\mathrm{H}_{2}$ (hySR)

$1 / 2 \mathbf{H}_{2(\mathrm{aq})}+1 / 8 \mathrm{SO}_{4(\mathrm{aq})}^{2-}+1 / 8 \mathrm{H}_{(\mathrm{aq})}^{+} \rightarrow 1 / 8 \mathrm{HS}_{(\mathrm{aq})}^{-}+$ $1 / 2 \mathrm{H}_{2} \mathrm{O}_{(1)}$

$R_{4}$ Sulfate Reduction with Ac (acSR)

$1 / 8 \mathbf{C H}_{3} \mathbf{C O O}_{(\mathrm{aq})}^{-}+1 / 8 \mathrm{SO}_{4(\mathrm{aq})}^{2-} \rightarrow 1 / 8 \mathrm{HS}_{(\mathrm{aq})}^{-}+$ $1 / 4 \mathrm{HCO}_{3(\mathrm{aq})}^{-}$

$R_{5}$ Methanogenesis with $\mathrm{H}_{2}$ (hyME)

$1 / 2 \mathbf{H}_{2(\mathrm{aq})}+1 / 8 \mathrm{HCO}_{3(\mathrm{aq})}^{-}+1 / 8 \mathrm{H}_{(\mathrm{aq})}^{+} \rightarrow 1 / 8 \mathrm{CH}_{4(\mathrm{aq})}+$ $3 / 8 \mathrm{H}_{2} \mathrm{O}_{(1)}$

$R_{6}$ Methanogenesis with Ac (acME)

$1 / 8 \mathrm{CH}_{3} \mathrm{COO}_{(\mathrm{aq})}^{-}+1 / 8 \mathrm{H}_{2} \mathrm{O}_{(1)} \rightarrow 1 / 8 \mathrm{CH}_{4(\mathrm{aq})}+$ $1 / 8 \mathrm{HCO}_{3(\mathrm{aq})}^{-}$

$R_{7}$ AnAerobic Oxidation of Methane (AOM) ${ }^{\dagger}$

$1 / 8 \mathbf{C H}_{4(\mathrm{aq})}+3 / 8 \mathrm{H}_{2} \mathrm{O}_{(1)} \rightarrow 1 / 2 \mathrm{H}_{2(\mathrm{aq})}+1 / 8 \mathrm{HCO}_{3(\mathrm{aq})}^{-}$

$+1 / 8 \mathrm{H}_{(\mathrm{aq})}^{+}$

$R_{8} \quad$ Acetogenesis (acet)

$1 / 2 \mathbf{H}_{2(\mathrm{aq})}+1 / 4 \mathrm{HCO}_{3(\mathrm{aq})}^{-}+1 / 8 \mathrm{H}_{(\mathrm{aq})}^{+} \rightarrow$ $1 / 8 \mathrm{CH}_{3} \mathrm{COO}_{(\mathrm{aq})}^{-}+1 / 2 \mathrm{H}_{2} \mathrm{O}_{(1)}$

$R_{9}$ ACETOTROPHY (actr)

$1 / 8 \mathrm{CH}_{3} \mathbf{C O O}_{(\mathrm{aq})}^{-}+1 / 2 \mathrm{H}_{2} \mathrm{O}_{(1)} \rightarrow 1 / 2 \mathrm{H}_{2(\mathrm{aq})}+$ $1 / 4 \mathrm{HCO}_{3(\mathrm{aq})}^{-}+1 / 8 \mathrm{H}_{(\mathrm{aq})}^{+}$

Gas transfer processes

$R_{10}$ Methane Gas Formation

$\mathrm{CH}_{4(\mathrm{aq})} \rightarrow \mathrm{CH}_{4(\mathrm{~g})}$

$R_{11}$ Methane Gas Dissolution

$$
\mathrm{CH}_{4(\mathrm{~g})} \rightarrow \mathrm{CH}_{4(\mathrm{aq})}
$$

Rate M1 baseline Rate M5 baseline

$$
\min \rightarrow \max \quad \min \rightarrow \max
$$

1233

332

$1130 \rightarrow 1262$

194

$275 \rightarrow 427$

$178 \rightarrow 198$

58

963

709

$909 \rightarrow 1010$

$515 \rightarrow 985$

362

108

$339 \rightarrow 378$

$76 \rightarrow 146$

0

0

$2 \rightarrow 3^{3}$

$0 \rightarrow 1^{1}$

24

111

$20 \rightarrow 24$

$76 \rightarrow 178$

0

0

24

$24 \rightarrow 27$

$5 \rightarrow 11^{8}$

${ }^{\dagger} \mathrm{AOM}$ is assumed to be the reverse of bicarbonate methanogenesis $\left(R_{5}\right)$ (Hoehler et al., 1994), but see discussion by Nauhaus et al. (2005). 
Table 2. Biogeochemical parameters used to describe the rate of substrate uptake (Eq. 6) at M1 and M5. Maximum substrate uptake rates $\left(v_{\max }\right)$ are calculated for a temperature of $278.15 \mathrm{~K}$ (Dale et $a l ., 2006)$ and depend on $T$ according to the function $f(T)$ in Eq. 5.

Parameter

$k_{\text {hYLAB }}$
$k_{\text {hyMID }}$
$k_{\text {hyREF }}$
$Q_{10}$
$K_{S O 4}$
$K_{H 2-h y S R}$
$K_{A c-a c S R}$
$K_{H 2-h y M E}$
$K_{A c-a c M E}$
$K_{C H 4}$

$K_{\text {H2-acet }}$

$K_{\text {Ac-acet }}$

$K_{D O C-f e r m}$

$v_{\max -h y S R}$

$v_{\max -a c S R}$

$v_{\max -h y M E}$

$v_{\max -a c M E}$

$v_{\max -A O M}$

$v_{\max \text {-acet }}$

$v_{\text {max-actr }}$

$v_{\max \text {-ferm }}$

$\chi$

$\Delta G_{B Q-h y S R}$

$\Delta G_{B Q-a c S R}$

$\Delta G_{B Q-h y M E}$

$\Delta G_{B Q-a c M E}$

$\Delta G_{B Q-A O M}$

$\Delta G_{B Q-a c e t}$

$\Delta G_{B Q-a c t r}$

$\Delta G_{B Q-f e r m}$
Description

Hydrolysis rate of $\mathrm{POC}_{\mathrm{LAB}}$

Hydrolysis rate of $\mathrm{POC}_{\mathrm{MID}}$

Hydrolysis rate of $\mathrm{POC}_{\mathrm{REF}}$

Temperature dependence of $v_{\max }$

Kinetic constant for $\mathrm{SO}_{4}^{2-}$ uptake

Kinetic constant for $\mathrm{H}_{2}$ for hySR

Kinetic constant for Ac for acSR

Kinetic constant for $\mathrm{H}_{2}$ for hyME

Kinetic constant for Ac for acME

Kinetic constant for $\mathrm{CH}_{4}$ for AOM

Kinetic constant for $\mathrm{H}_{2}$ for acetogenesis

Kinetic constant for Ac for acetotrophy

Kinetic constant for LMW-DOC for fermentation

Maximum rate of hySR

Maximum rate of acSR

Maximum rate of hyME

Maximum rate of acME

Maximum rate of AOM

Maximum rate of acetogenesis

Maximum rate of acetotrophy

Maximum rate of fermentation

Average stoichiometric number

Bioenergetic energy threshold for hySR

Bioenergetic energy threshold for acSR

Bioenergetic energy threshold for hyME

Bioenergetic energy threshold for acME

Bioenergetic energy threshold for AOM

Bioenergetic energy threshold for acetogenesis

Bioenergetic energy threshold for acetotrophy

Bioenergetic energy threshold for fermentation

Baseline value

(M1/M5)

$0.22 / 0.12$
$-/ 0.0035$
0

3.8 or $2.0^{\mathrm{a}}$

$1.0 \times 10^{-3}$

$1.0 \times 10^{-8}$

$1.0 \times 10^{-4}$

$1.0 \times 10^{-6}$

$5.0 \times 10^{-3}$

$1.5 \times 10^{-3}$

$1.0 \times 10^{-7}$

$1.0 \times 10^{-3}$

$1.0 \times 10^{-3}$

1.43

0.74

1.42

0.71

0.71

1.41

0.71

0.83

1.00

1.00

1.25

1.25

2.00

0.60

1.25

1.25

1.25
Units

$\mathrm{y}^{-}$

$\mathrm{y}^{-1}$

$\mathrm{y}^{-1}$

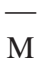

$\mathrm{M}$

$\mathrm{M}$

M

$\mathrm{M}$

$\mathrm{M}$

M

M

M

$\mathrm{mol} \mathrm{H}_{2} \mathrm{~L}^{-1} \mathrm{y}^{-1}$

mol Ac L ${ }^{-1} \mathrm{y}^{-1}$

$\mathrm{mol} \mathrm{H}_{2} \mathrm{~L}^{-1} \mathrm{y}^{-1}$

mol Ac L ${ }^{-1} \mathrm{y}^{-1}$

$\mathrm{mol} \mathrm{CH}_{4} \mathrm{~L}^{-1} \mathrm{y}^{-1}$

$\mathrm{mol} \mathrm{H}_{2} \mathrm{~L}^{-1} \mathrm{y}^{-1}$

mol Ac L ${ }^{-1} \mathrm{y}^{-1}$

$\mathrm{mol} \mathrm{C}_{6} \mathrm{H}_{12} \mathrm{O}_{6} \mathrm{~L}^{-1} \mathrm{y}^{-1}$

per electron

$\mathrm{kJ} \mathrm{mol}^{-1}$ (electrons)

$\mathrm{kJ} \mathrm{mol}^{-1}$ (electrons)

$\mathrm{kJ} \mathrm{mol}^{-1}$ (electrons)

$\mathrm{kJ} \mathrm{mol}^{-1}$ (electrons)

$\mathrm{kJ} \mathrm{mol}^{-1}$ (electrons)

$\mathrm{kJ} \mathrm{mol}^{-1}$ (electrons)

$\mathrm{kJ} \mathrm{mol}^{-1}$ (electrons)

$\mathrm{kJ} \mathrm{mol}^{-1}$ (electrons)

${ }^{\mathrm{a}} Q_{10}=3.8$ for terminal metabolism $\left(R_{3}-R_{9}\right.$, Table 1$)$ and 2.0 for hydrolysis and fermentation $\left(R_{1}, R_{2}\right)$. 
Table 3. Physical model parameters and boundary conditions used to constrain the baseline steady-state simulations (December 2004).

Baseline value $^{\mathrm{a}}$

\begin{tabular}{|c|c|c|c|c|}
\hline Parameter & Description & M1 & M5 & Unit \\
\hline$z$ & Water depth & 1500 & 2750 & $\mathrm{~cm}$ \\
\hline$L$ & Length of model domain & 700 & & $\mathrm{~cm}$ \\
\hline$S$ & Salinity & 27 & & - \\
\hline$T_{a v}$ & $\begin{array}{l}\text { Average bottom water } \\
\text { temperature }\end{array}$ & 281.15 & & $\mathrm{~K}$ \\
\hline$\varphi_{0}$ & Porosity at $x=0$ & $0.78^{\mathrm{b}}$ & $0.81^{b}$ & - \\
\hline$\varphi_{L}$ & Porosity at $x=L$ & 0.67 & 0.72 & - \\
\hline$\gamma$ & $\begin{array}{l}\text { Depth attenuation coefficient } \\
\text { for porosity }\end{array}$ & 0.009 & 0.03 & $\mathrm{~cm}^{-1}$ \\
\hline$v$ & Sediment accumulation rate & $0.02^{\mathrm{c}}$ & $0.20^{\mathrm{c}}$ & $\mathrm{cm} \mathrm{y}^{-1}$ \\
\hline$k_{s w}$ & $\begin{array}{l}\text { Thermal conductivity of } \\
\text { seawater }\end{array}$ & 0.006 & & $\mathrm{~W} \mathrm{~cm}{ }^{-1} \mathrm{~K}^{-1}$ \\
\hline$k_{d s}$ & $\begin{array}{l}\text { Thermal conductivity of dry } \\
\text { sediment }\end{array}$ & 0.025 & & 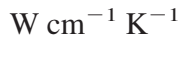 \\
\hline$\rho_{s w}$ & Density of seawater & 1.027 & & $\mathrm{~g} \mathrm{~cm}^{-3}$ \\
\hline$\rho_{d s}$ & Density of dry sediment & 2.500 & & $\mathrm{~g} \mathrm{~cm}^{-3}$ \\
\hline$c_{s w}$ & $\begin{array}{l}\text { Specific heat capacity of } \\
\text { seawater }\end{array}$ & 4.184 & & $\mathrm{~J} \mathrm{~g}^{-1} \mathrm{~K}^{-1}$ \\
\hline$c_{s}$ & $\begin{array}{l}\text { Specific heat capacity of dry } \\
\text { sediment }\end{array}$ & 0.300 & & $\mathrm{~J} \mathrm{~g}^{-1} \mathrm{~K}^{-1}$ \\
\hline$\alpha_{0}$ & $\begin{array}{l}\text { Bioirrigation coefficient at } \\
\quad x=0\end{array}$ & $18^{\mathrm{d}}$ & $20^{\mathrm{d}}$ & $y^{-1}$ \\
\hline$\beta_{1}$ & $\begin{array}{l}\text { Attenuation coefficient } 1 \text { for } \\
\text { bioirrigation }\end{array}$ & 14.0 & 15.0 & $\mathrm{~cm}^{-1}$ \\
\hline$\beta_{2}$ & $\begin{array}{l}\text { Attenuation coefficient } 2 \text { for } \\
\text { bioirrigation }\end{array}$ & 1.0 & & $\mathrm{~cm}^{-1}$ \\
\hline$D_{b 0}$ & $\begin{array}{l}\text { Bioturbation intensity in the } \\
\text { upper layers }\end{array}$ & $12^{\mathrm{e}}$ & & $\mathrm{cm}^{2} \mathrm{y}^{-1}$ \\
\hline$D_{S_{42}=}^{0}$ & Diffusion coefficient for $\mathrm{SO}_{4}^{2-}$ & $173^{\mathrm{f}}$ & & $\mathrm{cm}^{2} \mathrm{y}^{-1}$ \\
\hline$D_{D I C}^{O}$ & Diffusion coefficient for DIC & $160^{\mathrm{f}}$ & & $\mathrm{cm}^{2} \mathrm{y}^{-1}$ \\
\hline$D_{D O C}^{0}$ & $\begin{array}{l}\text { Diffusion coefficient for } \\
\text { LMW-DOC }\end{array}$ & $30^{\mathrm{g}}$ & & $\mathrm{cm}^{2} \mathrm{y}^{-1}$ \\
\hline$D_{A c}^{0}$ & Diffusion coefficient for Ac & $180^{\mathrm{f}}$ & & $\mathrm{cm}^{2} \mathrm{y}^{-1}$ \\
\hline$D_{H_{2}}^{0}$ & Diffusion coefficient for $\mathrm{H}_{2}$ & $744^{\mathrm{f}}$ & &. $\mathrm{cm}^{2} \mathrm{y}^{-1}$ \\
\hline $\mathrm{D}_{\mathrm{CH}_{4}}^{\mathrm{O}^{2}}$ & $\begin{array}{l}\text { Diffusion coefficient for } \\
\mathrm{CH}_{4(\mathrm{aq})}\end{array}$ & $283^{\mathrm{f}}$ & & $\mathrm{cm}^{2} \mathrm{y}^{-1}$ \\
\hline$D_{C H_{4(g)}}^{O}$ & Diffusion coefficient for $\mathrm{CH}_{4(\mathrm{~g})}$ & 1400 & 10000 & $\mathrm{~cm}^{2} \mathrm{y}^{-1}$ \\
\hline$k_{G F}$ & $\mathrm{CH}_{4(\mathrm{~g})}$ formation rate constant & $1 \times 10^{2}$ & & $\mathrm{y}^{-1}$ \\
\hline$k_{\text {diss }}$ & $\mathrm{CH}_{4(\mathrm{~g})}$ dissolution rate constant & $1 \times 10^{7}$ & & $\mathrm{M}^{-1} \mathrm{y}^{-1}$ \\
\hline$x_{\text {gas }}$ & $\begin{array}{l}\text { Approximate depth of } \mathrm{CH}_{4} \\
\text { bubbles }\end{array}$ & $300^{\mathrm{h}}$ & $100^{\mathrm{h}}$ & $\mathrm{cm}$ \\
\hline
\end{tabular}


Table 3. (Continued)

Boundary

conditions

$$
\begin{aligned}
& F_{P O C_{L A B}} \\
& F_{P O C_{M I D}} \\
& F_{P O C_{R E F}} \\
& A_{O}
\end{aligned}
$$

$\theta$

$\tau$

$\mathrm{C}_{0-\mathrm{SO}_{4}^{2-}}$

$C_{0-D I C}$

$C_{0-D O C}$

$C_{0-A c}$

$\mathrm{C}_{\mathrm{O}-\mathrm{H}_{2}}$

$\mathrm{C}_{\mathrm{O}-\mathrm{CH}_{4}}$

$\mathrm{C}_{\mathrm{O}-\mathrm{CH}_{4(g)}}$

$\mathrm{C}_{\mathrm{L}-\mathrm{CH}_{4(g)}}$

$C_{L}$
Description

Flux of $\mathrm{POC}_{\mathrm{LAB}}$ to SWI

Flux of $\mathrm{POC}_{\mathrm{MID}}$ to SWI

Flux of $\mathrm{POC}_{\mathrm{REF}}$ to SWI

Seasonal amplitude in $T_{S W I}$

(Eq. 13)

Phase lag at the SWI (Eq. 13 \&

16)

Period of the seasonal signal

(Eq. 13 \& 16)

Measured $\mathrm{SO}_{4}^{2-}$ concentration at $x=0$

Estimated DIC concentration at $x$ $=0$

Estimated LMW-DOC

concentration at $x=0$

Estimated Ac concentration at $x$ $=0$

Estimated $\mathrm{H}_{2}$ concentration at $x$ $=0$

Estimated $\mathrm{CH}_{4(\mathrm{aq})}$ concentration at $x=0$

Estimated $\mathrm{CH}_{4(\mathrm{~g})}$ concentration at $x=0$

Concentration of $\mathrm{CH}_{4(\mathrm{~g})}$ at $x=L$

All other species at $x=L$
Baseline value $^{\mathrm{a}}$

M1

M5

Unit

$\begin{array}{lll}4.5 \times 10^{-4} & 1.0 \times 10^{-4} & \mathrm{~mol} \mathrm{~cm}^{-2} \mathrm{y}^{-1} \\ 0.0 & 2.3 \times 10^{-5} & \mathrm{~mol} \mathrm{~cm}^{-2} \mathrm{y}^{-1} \\ 2.5 \times 10^{-5} & 2.7 \times 10^{-4} & \mathrm{~mol} \mathrm{~cm} \mathrm{y}^{-1} \\ \quad 6.5 & & \mathrm{~K}\end{array}$

0.58

y

y

22000

$\mu \mathrm{M}$

2000

$\mu \mathrm{M}$

5

$\mu \mathrm{M}$

2.0

$\mu \mathrm{M}$

0.1

$\mathrm{nM}$

1.0

$\mu \mathrm{M}$

0.0

$\%$

3.0

$\%$

${ }^{\mathrm{a}} \mathrm{A}$ single value applies to both cores.

${ }^{\text {b}}$ Porosity, $\varphi$, at any depth, $x$, is calculated by: $\varphi=\varphi_{L}+\left(\varphi_{0}-\varphi_{L}\right) \exp (\gamma \cdot x)$.

${ }^{\mathrm{c}}$ Approximated from ${ }^{14} \mathrm{C}$ analysis (J. Jensen, pers. comm.).

${ }^{\mathrm{d} B i o i r r i g a t i o n,} \alpha$, at any depth, $x$, is calculated by:

$$
\alpha=\alpha_{0} \cdot \exp \left(\frac{\beta_{1}-x}{\beta_{2}}\right) / 1+\exp \left(\frac{\beta_{1}-x}{\beta_{2}}\right)
$$

${ }^{\mathrm{e}}$ If $0<x<12 \mathrm{~cm}, D_{b}=D_{b 0}$. If $x>12 \mathrm{~cm}, D_{b}=11.0 \exp \left(-0.378\left(x-D_{b 0}\right)\right)$ (Fossing et al., 2004).

${ }^{\mathrm{f}}$ Value corresponds to infinite dilution in seawater at $5^{\circ} \mathrm{C}$ (Schulz, 2000).

${ }^{\mathrm{g}}$ From Dale et al. (2008).

${ }^{\mathrm{h}}$ Determined by seismic survey (Laier and Jensen, 2007). 
no direct measurements were available to constrain the $\mathrm{CH}_{4(\mathrm{~g})}$ transport rate. This permitted $\mathrm{CH}_{4(\mathrm{~g})}$, which accumulates at depth below the sulfate-reducing zone, to diffuse upwards through the sediment and re-dissolve if the pore water was under-saturated with $\mathrm{CH}_{4(\mathrm{~g})}$ (see below). This approach is fully mass conservative and avoids the use of non-local sink terms to remove the accumulating gas (Martens et al., 1998).

The dependence of $D_{S}$ on porosity and temperature $(T, \mathrm{~K})$ followed Boudreau (1997):

$$
D_{S}=\frac{D_{S}^{0}}{1-\ln \left(\varphi^{2}\right)}(1+\lambda)(T-273.15)
$$

where $D_{S}^{0}$ is the value for diffusion in seawater at $0{ }^{\circ} \mathrm{C}$ (Table 3), $1 /\left(1-\ln \left(\varphi^{2}\right)\right)$ and $(1+\lambda)$ corrects for tortuosity and $T$, respectively. $\lambda$ values for each dissolved species were calculated from Boudreau (1997). The $T$-dependency of $D_{\mathrm{CH} 4(\mathrm{~g})}$ in addition to $D_{b}$ and $\alpha$, required for the transient simulations, was not considered in the model. The validity of this assumption is tested in section 3 biii.

ii. Organic carbon decomposition and substrate turnover. POC deposited at the sea floor was degraded in the model to LMW-DOC by extracellular hydrolysis $\left(R_{1}\right.$; Table 1$)$ (Brüchert and Arnosti, 2003). The hydrolysis rate (mol C g-1 $\mathrm{y}^{-1}$ ) of each POC fraction, $j$, was described by:

$$
\begin{gathered}
R_{1}=\sum_{j} f(T) k_{h y-j}\left[\mathrm{POC}_{-j}\right] \\
\text { where } f(T)=Q_{10}^{\left(T-T_{r e f}\right) / 10}
\end{gathered}
$$

where $k_{h y-j}$ refers to the first-order decay constants $\left(\mathrm{y}^{-1}\right)$ for the $j^{\text {th }}$ fraction of POC $\left(k_{h y L A B}\right.$, $k_{\text {hyMID }}$ and $\left.k_{\text {hyREF }}\right)$ and $f(T)$ is the $T$-dependency of hydrolysis relative to the reference temperature, $T_{\text {ref }}$ (see below). Fermentation of LMW-DOC to DIC, Ac and $\mathrm{H}_{2}\left(R_{2}\right.$, Table 1 , Burdige, 2006) provided the substrates for the terminal metabolic processes in the reaction network $\left(R_{3}-R_{9}\right)$.

Steady-state microbial biomasses were assumed based on the premise that microbial activity rather than total cell numbers exerts the main control on substrate turnover in typical coastal marine sediments (Dale et al., 2006). The reaction rate for each catabolic pathway $\left(R_{3}-R_{9}\right)$, including fermentation $\left(R_{2}\right)$, for the specified stoichiometries was determined by:

$$
\begin{gathered}
\frac{d \mathrm{E}_{\mathrm{D}}}{d t}=\sum_{i} f(T) v_{\max -i} F_{K-i} F_{T-i} \\
F_{K-i}=\left(\frac{\left[\mathrm{E}_{\mathrm{D}}\right]}{K_{E_{D}-i}+\left[\mathrm{E}_{\mathrm{D}}\right]}\right)\left(\frac{\left[\mathrm{E}_{\mathrm{A}}\right]}{K_{E_{A}-i}+\left[\mathrm{E}_{\mathrm{A}}\right]}\right)
\end{gathered}
$$




$$
F_{T-i}=\max \left[0,\left(1-\exp \left(\frac{\Delta G_{I N S I T U-i}+\Delta G_{B Q-i}}{\chi R T}\right)\right)\right]
$$

where $v_{\max -i}\left(\mathrm{~mol} \mathrm{E}_{\mathrm{D}} \mathrm{L}^{-1} \mathrm{y}^{-1}\right)$ is the maximum rate of electron donor $\left(\mathrm{E}_{\mathrm{D}}\right)$ utilization by the $i$-th catabolic pathway, and $F_{K}$ and $F_{T}$ are the dimensionless kinetic and thermodynamic drives for the reaction (Jin and Bethke, 2005). In Eq. 7, $\mathrm{E}_{\mathrm{D}}$ and $\mathrm{E}_{\mathrm{A}}$ represent the electron donor and acceptor of the catabolic reaction, respectively, with corresponding halfsaturation constants ( $K_{E D / E A-I}$; Dale et al. (2008)), $\Delta G_{I N S I T U}\left(\mathrm{~kJ} \mathrm{~mol}^{-1}\right.$ electrons) is the in situ (non-standard) Gibbs energy yield of the catabolic process and $\Delta G_{B Q}\left(\mathrm{~kJ} \mathrm{~mol}^{-1}\right.$ electrons) is the Gibbs energy threshold for catabolism (assumed to be $T$-independent without supporting data), $\chi$ is the average stoichiometric number (Jin and Bethke, 2005) and $R$ is the gas constant $\left(8.314 \mathrm{~J} \mathrm{~K}^{-1} \mathrm{~mol}^{-1}\right) . F_{K}$ and $F_{T}$ vary between 0 (total limitation of $\mathrm{E}_{\mathrm{D}}$ uptake) and 1 (no limitation). The product of $F_{K}$ and $F_{T}$ gives the total drive for reaction. Parameter values are summarized in Table 2.

The $v_{\max -i}$ values were calculated from the microbial growth yields following the approach of Dale et al. (2008) using a mean biomass concentration for Aarhus Bay of approximately $7.5 \times 10^{8}$ cells cm$~_{-3}$ (B. Cragg, pers. comm.). The Arrhenius $f(T)$ term in Eq. 6 provides the $T$-dependency of $v_{\max -i}$ relative to the reference temperature, $T_{\text {ref }}$, of $278.15 \mathrm{~K}$. A $Q_{10}$ value of 3.8 has been determined experimentally for sulfate reduction in Aarhus Bay by Fossing et al. (2004) and we assumed that this $Q_{10}$ value was applicable for the microbial processes $R_{3}-R_{9}$ in Table 1 . A $Q_{10}$ value of 2.0 was prescribed for hydrolysis and fermentation $\left(R_{1}-R_{2}\right)$ since their temperature response has been observed to be approximately half that for SR (Weston and Joye, 2005).

$\Delta G_{I N S I T U}$ was calculated from the chemical composition of the pore water using:

$$
\Delta G_{\text {INSITU }}=\Delta G^{\circ \prime}+R T \ln Q
$$

where $\Delta G^{\circ \prime}$ is the standard Gibbs energy of catabolism ( $\mathrm{kJ} \mathrm{mol}^{-1}$ electrons) at $281.15 \mathrm{~K}$ and corrected for biologically neutral $\mathrm{pH}$ conditions (Dale et al., 2006), and $Q$ represents the activity quotient using activity coefficients from Dale et al. (2008). $\Delta G^{\circ \prime}$ values were not corrected for $T$ in the transient simulations because the reaction rates change by only $<1 \%$ within the range $276.15-289.15 \mathrm{~K}$. For sulfate reduction $\left(R_{3}-R_{4}\right)$, the measured sulfide concentration $(2.0 \mathrm{mM})$ in the SMTZ was used to calculate $\Delta G_{I N S I T U}$.

iii. Dissolved and gaseous methane. Exchange of methane between the dissolved and gaseous phases was assumed to be proportional to the departure between dissolved methane, $\mathrm{CH}_{4(\mathrm{aq})}$, and the local solubility concentration, $\mathrm{CH}_{4}^{*}$. The rates of gas formation, $R_{G F}$, and dissolution, $R_{\text {diss }}$, were described by $\left(R_{10-11}\right.$, Table 1$)$ :

$$
\begin{gathered}
R_{G F}=k_{G F}\left(\mathrm{CH}_{4(\mathrm{aq})}-\mathrm{CH}_{4}^{*}\right) \text { for } \mathrm{CH}_{4(\mathrm{aq})}>\mathrm{CH}_{4}^{*} \\
R_{\text {diss }}=k_{\text {diss }}\left(\mathrm{CH}_{4}^{*}-\mathrm{CH}_{4(\mathrm{aq})}\right) \mathrm{CH}_{4(\mathrm{~g})} \text { for }\left\{\begin{array}{c}
\mathrm{CH}_{4(\mathrm{aq})}<\mathrm{CH}_{4}^{*} \\
\text { and } \\
\mathrm{CH}_{4(\mathrm{~g})}>0
\end{array}\right.
\end{gathered}
$$


where $k_{G F}\left(\mathrm{y}^{-1}\right)$ and $k_{\text {diss }}\left(\mathrm{M}^{-1} \mathrm{y}^{-1}\right)$ are the corresponding rate constants. As a first approximation, the magnitude of the $k_{G F}$ and $k_{\text {diss }}$ were set sufficiently high to (i) prevent over-saturation of the pore water, and (ii) prevent the coexistence of $\mathrm{CH}_{4(\mathrm{~g})}$ and undersaturated pore water if $\mathrm{CH}_{4(\mathrm{aq})}<\mathrm{CH}_{4}^{*}$. The assumption is based on the observations that no bubbles were observed in the cores above the gas horizon (i.e. close to gas equilibrium conditions), and that the solute profiles above this depth showed no obvious signs of bubble-induced mixing of pore water.

$\mathrm{CH}_{4}^{*}\left(\mathrm{~mol} \mathrm{~L}^{-1}\right)$ depends on salinity $(S)$, temperature $(T)$ and pressure $(P)$. A numerical model for calculating $\mathrm{CH}_{4}^{*}$ over a wide range of $S, T$ and $P$ has been presented by Duan et al. (1992). Based on his work, we constructed a simplified, analytical approximation which is computationally efficient. Three successive linear regressions were performed to determine the dependence of $\mathrm{CH}_{4}^{*}$ on $S, T$ and $P$, respectively, which were then folded into a ruled hyper-surface and expressed by the following $3^{\text {rd }}$ degree polynomial:

$$
\begin{aligned}
\mathrm{CH}_{4}^{*}= & 1.4388 \times 10^{-7} \mathrm{STP}-4.412 \times 10^{-5} \mathrm{TP}-4.6842 \times 10^{-5} \mathrm{SP}+4.129 \times 10^{-9} \mathrm{ST} \\
& +1.43465 \times 10^{-2} \mathrm{P}-1.6027 \times 10^{-6} \mathrm{~T}-1.2676 \times 10^{-6} S+4.9581 \times 10^{-4}
\end{aligned}
$$

$\mathrm{CH}_{4}^{*}$ concentrations calculated with this formula predict $\mathrm{CH}_{4}^{*}$ for ranges of $S$ (1-35), $T$ (273.15-290.15 K) and $P(1-30 \mathrm{~atm})$ relevant to temperate aquatic environments and are identical to those derived from the fully-implicit iterative formulation of Duan et al. (1992) to within $\pm 3 \%$. The formula assumes that the total pressure of the gas in the sediment, $P$, is exclusively due to methane and water vapor (Duan et al., 1992). In this study, the contribution of other gases (e.g. $\mathrm{CO}_{2}, \mathrm{~N}_{2}$ ) was neglected since their dissolved concentrations in Aarhus Bay sediments, $\sim 500 \mu \mathrm{M} \mathrm{N} \mathrm{N}_{2}$ (assumed; Martens and Berner, 1977) and $\sim 700 \mu \mathrm{M} \mathrm{CO}_{2}$ (calculated), were well below their respective in situ solubility concentration.

iv. Heat transport and boundary conditions. In the baseline steady-state simulations used for the model calibration, boundary conditions for solutes and $\mathrm{CH}_{4(\mathrm{~g})}$ at the sediment-water interface (SWI) were imposed as fixed concentrations corresponding to either measured or existing literature values (Table 3). $T$ at the upper boundary was set to the value measured during sampling in December 2004 (281 K) and the flux of POC to the sediment surface was adjusted to fit the experimental data as described in the following section. Solutes and solids at the lower boundary were prescribed with zero concentration gradients (Table 3). For $\mathrm{CH}_{4(\mathrm{~g})}$, a fixed concentration equivalent to a volumetric gas content of $3 \%$ (gas volume/total sediment volume; see Martens et al. (1998) for calculation) was imposed at the base of the model. This value is based on previous estimates and measurements of gas content in Eckernförde Bay (Abegg and Anderson, 1997; Martens et al., 1998; Anderson et al., 1998; Mogollón et al., 2008) - an environment geochemically similar to Aarhus Bay.

Different boundary conditions were required for the transient simulations, where $T$ and POC were modified to represent the seasonal fluctuations at the SWI. The variation in $T$ at 
the SWI $\left(T_{S W I}\right)$ was implemented using a sinusoidal function between maximum and minimum values around the annual mean, $T_{a v}$ :

$$
T_{S W I}=T_{a v}+A_{0} \sin \left(\frac{2 \pi(t+\theta)}{\tau}\right)
$$

where $\tau(\mathrm{y})$ is the period of the signal and $A_{O}(\mathrm{~K})$ is the seasonal amplitude at the SWI. The phase lag, $\theta$ (y), synchronized the boundary condition with the measured $T$ data (Table 3 ). The spatial and temporal variation of $T$ was calculated by solving the heat transport equation subject to thermal diffusion:

$$
\frac{\partial T}{\partial t}=D_{T} \frac{\partial^{2} T}{\partial x^{2}}
$$

where $D_{T}\left(\mathrm{~cm}^{2} \mathrm{y}^{-1}\right)$ is the thermal diffusivity of the saturated sediment, calculated by:

$$
D_{T}=k_{s w}^{\varphi} k_{d s}^{(1-\varphi)}\left[\left(\rho_{s w} \varphi+\rho_{d s}(1-\varphi)\right)\left(c_{s w} \varphi+c_{d s}^{(1-\varphi)}\right)\right]^{-1}
$$

where $k$ is the thermal conductivity $\left(\mathrm{W} \mathrm{cm}^{-1} \mathrm{~K}\right), \rho$ is density $\left(\mathrm{g} \mathrm{cm}^{-3}\right), c$ is the specific heat capacity $\left(\mathrm{J} \mathrm{g}^{-1} \mathrm{~K}^{-1}\right)$, and subscripts $s w$ and $d s$ denote seawater and dry sediment, respectively (Woodside and Messmer, 1961) (Table 3). Due to the high thermal diffusivity, heat transport due to sediment burial, bioturbation and bioirrigation are negligible and ignored (see Section 3bi). The bottom of the model core $(700 \mathrm{~cm})$ experiences a negligible effect from the temperature variations in seawater, and a zero thermal gradient condition was prescribed for $T$ at the lower boundary.

The seasonal variability in POC deposition at the SWI $\left(F_{S W I}\right.$, mol C cm $\mathrm{cm}^{-2} \mathrm{y}^{-1}$ was also considered despite only being important in the uppermost sediment layers (Fossing et al., 2004). No data were available to accurately constrain $F_{S W I}$ and, therefore, a sinusoidal function was used, which sums the fluxes of each POC fraction, $j$ :

$$
F_{S W I}=\sum_{j} F_{P O C_{-j}}\left(1+\sin \left(\frac{2 \pi(t+\theta)}{\tau}\right)\right)
$$

where the average value of each flux $\left(F_{P O C-j}\right)$ was set to the value used in the baseline simulation (Table 1), so that the seasonal flux varied from 0 to $2 F_{P O C}$ in phase with $T_{S W I}$. This amplified the effect of seasonal variations and the simulations should therefore provide an upper limit for the intra-annual variability in sulfate and methane cycling.

\section{Results and discussion}

\section{a. Baseline simulations}

The model results for the baseline simulation of the sediment biogeochemistry at stations M1 and M5, calibrated using the data measured in fall 2004, are shown in Figure 1. The simulated $\mathrm{SO}_{4}{ }^{2-}$ and $\mathrm{CH}_{4(\mathrm{aq})}$ concentrations at M1 and M5 compare well with the 


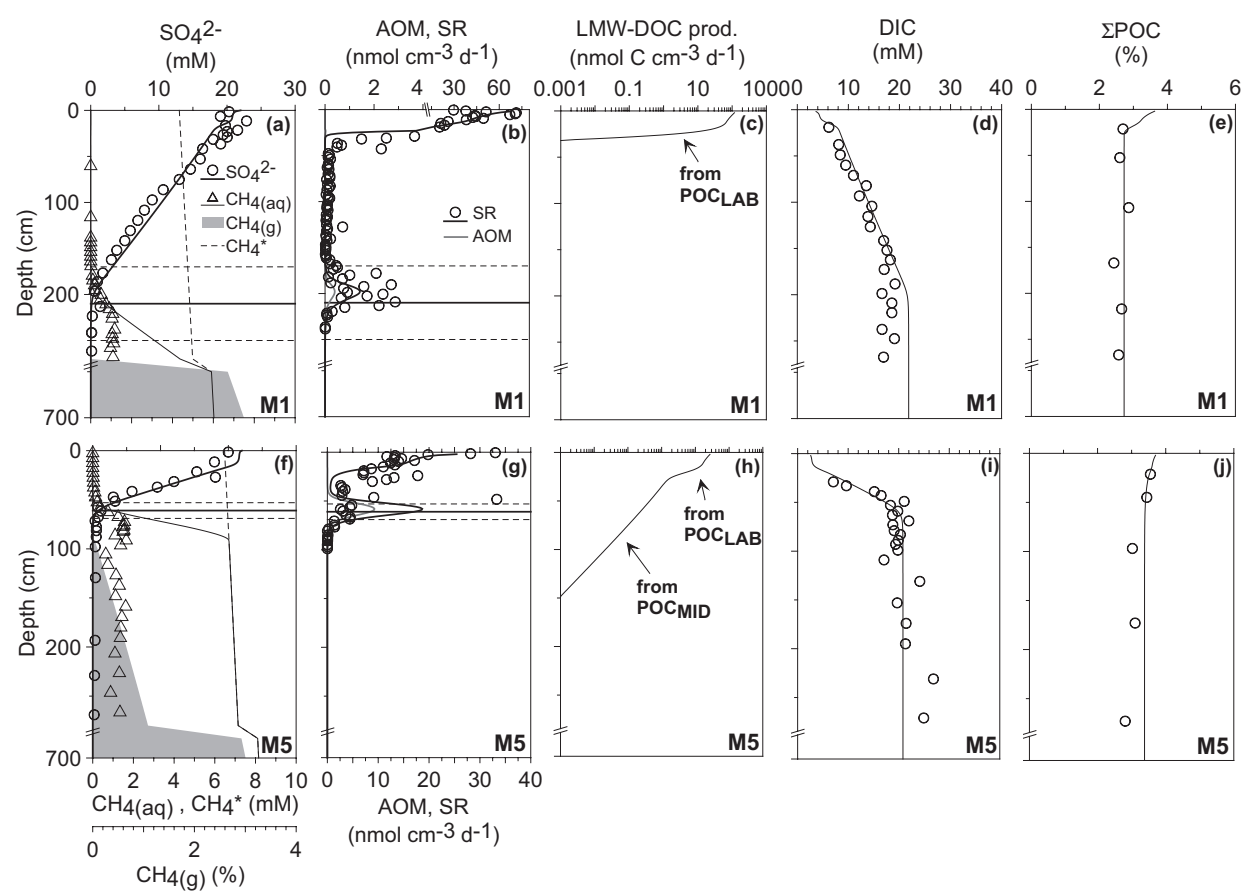

Figure 1. Steady-state, simulated (lines) geochemical and measured (points) profiles for December 2004 at stations M1 (top row) and M5 (bottom row). (a,f) $\mathrm{SO}_{4}^{2-}, \mathrm{CH}_{4(\mathrm{aq})}$, modeled $\mathrm{CH}_{4(\mathrm{~g})}$ (shaded) and $\mathrm{CH}_{4}^{*}$. $(b, g)$ Rate of sulfate reduction (SR) and AOM. (c,h) Rate of production of LMW-DOC. (d,i) DIC concentration, and (e,j) total POC concentration. The solid horizontal lines in $(\mathrm{a}, \mathrm{b}, \mathrm{f}, \mathrm{g})$ indicate the depth of the SMTZ $\left(z_{S M T Z}\right)$, and the dashed horizontal lines show the extent of variability of observed in samples from repeated coring at the same station. Note the breaks in the axes.

measured data (Fig. 1a,f), and the corresponding model results for the measured sulfate reduction (SR) rate (assumed to be the sum of hySR $\left(R_{3}\right)$ and acSR $\left(R_{4}\right)$, Table 1) also compare favorably (Fig. 1b,g). $k_{h y L A B}$ and $k_{h y M I D}$ (Eq. 4) were constrained from the measured SR rate above the SMTZ, since POC is almost entirely oxidized by SR below the top $5 \mathrm{~cm}$ (Fossing et al., 2004). The higher SR rate at M1 alludes to a higher abundance of labile organic substrate than at M5. At both sites, the SR rate presents two maxima; one at the surface and another deeper down at the SMTZ. Here, SR is coupled to the anaerobic oxidation of methane diffusing upwards from depth, which consumes methane at maximum rates of 1.4 and $9.3 \mathrm{nmol} \mathrm{cm}{ }^{-3} \mathrm{~d}^{-1}$ for M1 and M5, respectively, similar to ${ }^{14} \mathrm{CH}_{4}$ radiotracer AOM rates (Knab et al., unpublished data). The peak of the SMTZ, defined at the depth of equimolar $\mathrm{SO}_{4}^{2-}$ and $\mathrm{CH}_{4(\mathrm{aq})}$ concentrations, is located at $221 \mathrm{~cm}$ at $\mathrm{M} 1$ and 63 $\mathrm{cm}$ at M5 (solid horizontal lines). However, it is important to keep in mind that the SMTZ is not restricted to a single specific depth, but extends along a certain domain where $\mathrm{CH}_{4}$ and $\mathrm{SO}_{4}^{2-}$ coexist. Repeated coring over the 2 year sampling period further suggests that at both sites the SMTZ depth shifts vertically by up to $80 \mathrm{~cm}$ at M1 and $16 \mathrm{~cm}$ at M5 (dashed 
horizontal lines). This variability is not an artifact introduced by alignment of the two coring devices, since the variability is greater than the uncertainty ( $\pm 3 \mathrm{~cm}$ for M1 and M5) attributed to the sediment lost from the gravity core.

The different SMTZ depths in the baseline simulations between M1 $(221 \mathrm{~cm})$ and M5 $(63 \mathrm{~cm})$ cannot be attributed to an enhanced flux of $\mathrm{SO}_{4}^{2-}$ into the sediment by the mixing and burrowing action of indwelling fauna because the model data are simulated with identical rates of bioturbation and near-equivalent rates of bioirrigation (Table 3). It is more likely that the rate of LMW-DOC production by POC hydrolysis is the determining variable (Westrich and Berner, 1984; Brüchert and Arnosti, 2003). For example, decreased fermentation of LMW-DOC to Ac and $\mathrm{H}_{2}$ will lead to lower rates of SR and methanogenesis, enhanced $\mathrm{SO}_{4}^{2-}$ penetration into the sediment and a deeper SMTZ. At M1, best fits to the SR rates are attained with a LMW-DOC production rate at the surface $(130 \mathrm{nmol} \mathrm{C}$ $\mathrm{cm}^{-3} \mathrm{~d}^{-1} ;$ Fig $\left.1 \mathrm{c}\right)$ which is 4 times greater than at M5 $\left(31 \mathrm{nmol} \mathrm{C} \mathrm{cm}^{-3} \mathrm{~d}^{-1} ;\right.$ Fig $\left.1 \mathrm{~h}\right)$ possibly because the water column is only $15 \mathrm{~m}$ deep compared to $27 \mathrm{~m}$ at M5 and, thus, M1 receives a higher amount of labile POC (Table 3). Flushing of the pore water by bioirrigation prevents $\mathrm{SO}_{4}^{2-}$ from becoming depleted in the surface layers. Moreover, this labile carbon substrate is quickly exhausted below the bioturbated zone at M1 and LMW-DOC production decreases sharply at $25 \mathrm{~cm}$ depth. The apparent absence of SR between $25 \mathrm{~cm}$ and the top of the SMTZ $(160 \mathrm{~cm})$ thus indicates a lack of degradable POC according to the model (Fig. 1b). At M5, the measured rate profiles are best reproduced using the additional mineralization of $\mathrm{POC}_{\mathrm{MID}}$, which contributes to hydrolysis below the upper layers (Fig. 1h). This leads to more uptake of $\mathrm{SO}_{4}^{2-}$ below the irrigated zone and reduced penetration of $\mathrm{SO}_{4}^{2-}$ into the sediment. Integrated over the whole sediment, SR equals $603 \mathrm{nmol} \mathrm{cm} \mathrm{d}^{-1}$ at M1 and $397 \mathrm{nmol} \mathrm{cm}^{-2} \mathrm{~d}^{-1}$ at M5 (Table 1), which are comparable to the measured rate of $470 \mathrm{nmol} \mathrm{cm}^{-2} \mathrm{~d}^{-1}$ in the upper mixed layer of Aarhus Bay reported by Thamdrup et al. (1994). At both $\mathrm{M} 1$ and $\mathrm{M} 5,>90 \%$ of the $\mathrm{SO}_{4}^{2-}$ is supplied by bioirrigation, with the remaining fraction supplied by diffusion, bioturbation and input through burial. It must be noted, however, that the fraction of $\mathrm{SO}_{4}{ }^{2-}$ added by bioirrigation implicitly accounts for the recycling of $\mathrm{SO}_{4}^{2-}$ by re-oxidation of hydrogen sulfide using $\mathrm{O}_{2}$ (Glud et al., 2003; Fossing et al., 2004); a process not included in the model.

The importance of the labile substrate in the upper layers at M1 is further supported by the low ratio of the depth integrated rates of AOM to total SR, which is a measure of the significance of methane as substrate source for SR. AOM fuels only $4 \%$ of SR at M1 compared to $28 \%$ at M5, despite the very obvious draw down of $\mathrm{SO}_{4}^{2-}$ to the $\mathrm{SMTZ}$ at M1. These findings broadly agree with observations by Dale et al. (2008) for Skagerrak sediments, whereby the POC depositional conditions and relative rates of terminal metabolism can exhibit large differences within the same local geographical area.

The total rate of carbon degradation in the sediment was constrained by the measured DIC concentration (Fig 1d,i). The DIC shows a more gradual increase with depth at M1 than M5, even though surface SR rates were far higher. This arises from more rapid 
removal, through irrigation, of the DIC produced from $\mathrm{POC}_{\mathrm{LAB}}$. At M5, the mineralization of $\mathrm{POC}_{\mathrm{MID}}$ below the irrigated zone allows DIC to accumulate. At both stations, the DIC concentration stabilizes below the SMTZ, suggesting that there is very little mineralization of $\mathrm{POC}_{\mathrm{REF}}$ in the sediment. This result is also supported by the uniform POC concentration profiles (Fig. 1e,j). On this basis, the reactivity of $\operatorname{POC}_{\mathrm{REF}}\left(k_{\text {hyREF }}\right)$ was set to zero, which means that methanogenesis does not take place in the deeper sediment layers because there is no burial of reactive POC below the SMTZ. In reality, methanogenesis actually occurs in the sediment (B. Cragg, pers. comm.) but the rates are not easily resolvable from the DIC data. Therefore, in order to fit the measured methane data and the depths of free methane gas observed on the seismic profiles $(\sim 300 \mathrm{~cm}$ at $\mathrm{M} 1$ and $\sim 100 \mathrm{~cm}$ at M5; Laier and Jensen, 2007) (Fig. 1a,f), a source of methane gas had to be specified at the lower model boundary. $D_{\mathrm{CH} 4(\mathrm{~g})}$ was then constrained by fitting the depth of the SMTZ, and set equal to $1400 \mathrm{~cm}^{2} \mathrm{y}^{-1}$ at M1 and $10000 \mathrm{~cm}^{2} \mathrm{y}^{-1}$ M5 (Table 3). An alternative model approach would, obviously, be to attribute all the $\mathrm{CH}_{4(\mathrm{~g})}$ to the in situ production from $\mathrm{POC}_{\mathrm{REF}}$ mineralization. However, this resulted in DIC concentrations up to 6 times higher than measured (data not shown); a finding which confirms that in situ methanogenesis rates must be low throughout the core.

Together, the model provides compelling evidence that the $\mathrm{CH}_{4(\mathrm{~g})}$ in these cores either (i) ascends in the sediment along lateral unconformities or cracks in the sediment matrix (Boudreau et al., 2005) or (ii) originates from a deeper, organic-rich sediment deposited during the initial stages of the Holocene transgression (Jensen and Laier, 2003; Laier and Jensen, 2007). Transport of $\mathrm{CH}_{4(\mathrm{~g})}$ from the underlying deep late glacial sediments is unlikely since they contain very little organic matter (Jensen and Laier, 2003). The sampling campaign was not designed to investigate the mechanisms of gas transport, and this issue remains unresolved. Further chemical analysis of deep sedimentary layers, including pore water $\delta^{13} \mathrm{C}$ data, may be needed to support either hypothesis.

\section{b. Transient simulations}

Seasonal forcings of $T$ and POC flux to the SWI at M1 and M5 are described by Eq. 13 and (16). All other internal model parameters and boundary conditions remain unchanged from the baseline simulations described above. Imparting from the baseline simulations as initial conditions, the simulations are tracked with the time-varying boundary conditions until yearly-averaged steady state is reached. At this point, there is no inter-annual variability in $T$, species concentrations or rates for any given day of the year.

i. T and POC forcings. Temperature affects the magnitude of transport and reaction by impacting on $v_{\max }$ through $f(T), F_{T}$ directly through $T$ and indirectly through $\Delta G_{I N S I T U}$, the solute diffusion coefficients, $D_{S}$, and the methane solubility, $\mathrm{CH}_{4}^{*}$. Due to lack of data, bioturbation and bioirrigation were assumed independent of $T$. The implications of this assumption are briefly addressed below. 
Figure 2a compares the measured bottom water temperature $\left(T_{S W I}\right)$ in Aarhus Bay during the entire year of 2004 with the temperature imposed at the sediment surface in the model. $T_{S W I}$ shows a variation of $13 \mathrm{~K}$, between $276 \mathrm{~K}\left(3^{\circ} \mathrm{C}\right)$ in winter (February) and 289 $\mathrm{K}\left(16^{\circ} \mathrm{C}\right)$ in summer (August), which is typical for this environment (Thamdrup et al., 1994; Glud et al., 2003). Although the measured data show a departure between the start and end of the year, the intra-annual variability is significantly larger and can be approximated with a sinusoidal function.

The transient $T$ profiles in the sediment were calculated by integrating Eq. 14 using $T_{S W I}$ as an upper boundary condition. No experimental data are available to verify the modeled $T$ distribution, yet studies have shown that heat propagation in sediments can be faithfully reproduced from porosity data and the fundamental thermal properties of sea water and sedimentary material (Woodside and Messmer, 1961). For instance, the calculated thermal diffusivity $\left(D_{T}\right)$ corresponding to $281.65 \mathrm{~K}$ and a porosity of 0.74 is $6.2 \times 10^{5} \mathrm{~cm}^{2} \mathrm{y}^{-1}$, which is similar to values reported by Matisoff (1980) and Jackson and Richardson (2001) for marine sediments. The theoretical seasonal evolution of $T$ predicted by Eq. 14 is shown in Figure $2 \mathrm{~b}$ and displays an e-folding depth of $120 \mathrm{~cm}$ (the depth at which the seasonal amplitude of $T$ decreases to 1/e of its value at the sediment surface), which is again comparable to calculations based on measured vertical $T$ profiles (Matisoff, 1980; Westrich and Berner, 1984; Jackson and Richardson, 2001). The time-lag in diffusion of heat through the sediment occasionally produces inverted profiles where $T$ is greater at depth than at the surface (e.g. January) in addition to non-monotonous profiles where transient maxima and minima with depth are generated (e.g. May and November).

The reduced seasonal amplitude of $T$ variations at the depth of the SMTZ $\left(z_{S M T Z}\right)$ is also very obvious (Fig. 2b), with a change of $\sim 10 \mathrm{~K}$ at M5 and only $\sim 3 \mathrm{~K}$ at M1 where the SMTZ is deeper. This variation is plotted for M1 and M5 against $T_{S W I}$ in Figure $2 \mathrm{c}, \mathrm{d}$, revealing a cyclic variation of heat at these sites. The time lag and dampening of $T$ with depth results in a Lissajous curve, which means that when $276.15 \mathrm{~K}<T_{S W I}<289.15 \mathrm{~K}$, two different possible values of $T$ can be obtained in the SMTZ for a given $T_{S W I}$, depending on whether $T_{S W I}$ is increasing (winter-to-summer) or decreasing (summer-to-winter). The eccentricity of the resulting ellipsoid is more pronounced for M5 since the SMTZ is located closer to the SWI and experiences less time-lag and thermal dampening through the sediment. In contrast, $T_{S M T Z}$ at M1 experiences a greater degree of decoupling from $T_{S W I}$ and shows a broader, more horizontal loop. Here, the maximum $T_{S M T Z}$ occurs in November; 3 months after the surface maxima in August. This suggests that time-lags in microbial substrate turnover rates driven by changes in $T$ can be expected to increase with increasing depth into the sediment. It follows also that the dynamics of $\mathrm{CH}_{4}$ dissolution and $\mathrm{CH}_{4(\mathrm{~g})}$ formation, which are directly dependent on solubility (Eq. 10-12), will present similar lags.

The seasonal change in modeled POC concentration is only apparent in the uppermost few $\mathrm{cm}$ of the sediment, despite the relatively large seasonal amplitude in depositional flux (Eq. 16) (data not shown). Below the upper mixed depth $(25 \mathrm{~cm})$, the POC concentration is 

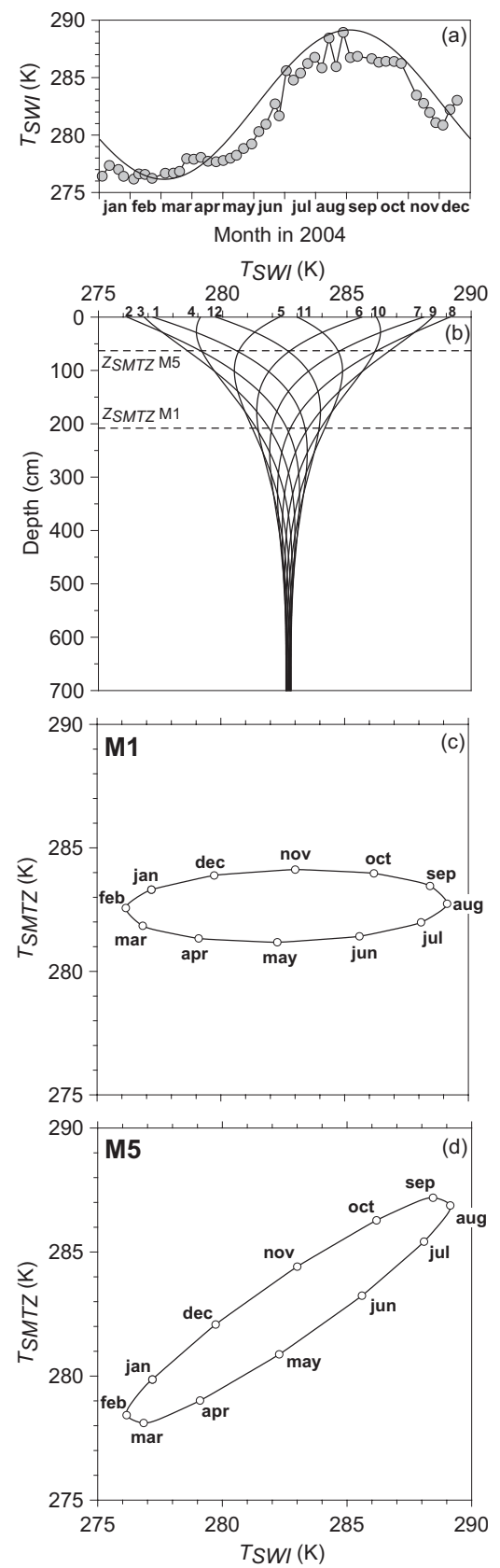

Figure 2. (a) Bottom water temperature $\left(T_{S W I}\right)$ measured during 2004 (points) and $T_{S W I}$ imposed on the transient simulations. (b) Depth distribution of $T$ in the sediment at M1; the $T$ distribution for M5 is almost identical. Each line corresponds to a calendar month indicated by the numerals on the upper axis. The horizontal dashed lines indicate the depth of the SMTZ $\left(z_{S M T Z}\right)$ at M1 and M5. (c,d) Annual evolution of $T$ at $z_{S M T Z}\left(T_{S M T Z}\right)$ against $T_{S W I}$ for M1 and M5. 
constant throughout the year and shows no seasonal signal. An order of magnitude for the age of the particulate material in the bioturbated layer can be approximated by the ratio of the bioturbation depth $(20 \mathrm{~cm})$ and the burial rate $\left(0.2 \mathrm{~cm} \mathrm{y}^{-1}\right)$ as $100 \mathrm{y}$ (at M5). Since the periodicity of the POC input is only $1 \mathrm{y}$, the burial rate is too slow, even at M5, to allow the seasonal variability in POC flux to be preserved in the sediment profiles (c.f. Burdige, 2006).

ii. Seasonal dynamics of redox processes. The maximum seasonal change in modeled methane $\left(\Delta \mathrm{CH}_{4(\mathrm{aq})}\right)$ and sulfate $\left(\Delta \mathrm{SO}_{4}^{2-}\right)$ concentrations and rates $(\Delta \mathrm{SR}$ and $\Delta \mathrm{AOM})$ are shown in Figure 3. The intra-annual variability reveals contrasting patterns at M1 and M5 owing to the different rates and depth distribution of LMW-DOC production and $T$ discussed previously. This is expressed in a large $\Delta \mathrm{SO}_{4}^{2-}$ in the surface layers at $\mathrm{M} 1$ of 700 nmol cm${ }^{-3}$ (Fig. 3a) and a maximum $\Delta$ SR of $60 \mathrm{nmol} \mathrm{cm}^{-3} \mathrm{~d}^{-1}$ (Fig. 3b). At M5, which receives less $\mathrm{POC}_{\mathrm{LAB}}, \Delta \mathrm{SO}_{4}^{2-}$ and $\Delta \mathrm{SR}$ are significantly lower (Fig. 3c,d). The integrated rates of SR range from 566-631 nmol SO $4_{4}^{2-} \mathrm{cm}^{-2} \mathrm{~d}^{-1}$ at $\mathrm{M} 1$ and 205-392 $\mathrm{nmol} \mathrm{SO}_{4}^{2-} \mathrm{cm}^{-2} \mathrm{~d}^{-1}$ at M5 (Table 1). For comparison, this is much lower than measured for Cape Lookout Bight (3300-7800 nmol cm $\mathrm{d}^{-1}$ ) where organic carbon mineralization rates are roughly 10 times higher (Crill and Martens, 1987). The seasonal differences in the STMZ are even more pronounced, with much larger changes in $\Delta \mathrm{SO}_{4}^{2-}, \Delta \mathrm{CH}_{4(\mathrm{aq})}, \Delta \mathrm{SR}$ and $\Delta \mathrm{AOM}$ at M5 compared to M1 (Fig. 3) due to the higher seasonal variation of $T$ at M5 $(10 \mathrm{~K}$, and $3 \mathrm{~K}$ at M1) (Fig. 2b). Thus, whereas the seasonal change in substrate turnover at the surface is mostly driven by the organic carbon input (Westrich and Berner, 1988), temperature is the major factor driving the variation in rates in the SMTZ. The seasonal range in the depth integrated AOM rate ( $\Sigma$ AOM, Table 1$)$ is small at M1 $\left(20-24 \mathrm{nmol} \mathrm{cm}^{-2} \mathrm{~d}^{-1}\right)$ and much larger at M5 (76-178 $\left.\mathrm{nmol} \mathrm{cm} \mathrm{d}^{-1}\right)$, the latter being comparable to Eckernförde Bay (51-150 nmol cm $\mathrm{nd}^{-1}$; Treude et al., 2005). Overall, the maximum variability in SR and AOM rates in the SMTZ is roughly equal in magnitude to the baseline values at M1 (Fig. 1b) and M5 (Fig. 1f).

The depth of the gas horizon below the SMTZ may also be important for the seasonal variability in methane cycling because $T$-induced changes in gas solubility will impact on $\mathrm{CH}_{4(\mathrm{aq})}$ concentration. At M5, $\mathrm{CH}_{4(\mathrm{aq})}$ concentration exhibits seasonal changes of 820 $\mathrm{nmol} \mathrm{cm}{ }^{-3}$ compared to only $150 \mathrm{nmol} \mathrm{cm}^{-3}$ at M1 (Fig. 3a,c). Moreover, free gas is located more closely to the SMTZ at M5 whereas at M1 changes in $\mathrm{CH}_{4(\mathrm{aq})}$ concentration due to gas formation and dissolution occur more than $50 \mathrm{~cm}$ below the SMTZ. Consequently, whereas the modeled annual evolution of $\Sigma \mathrm{AOM}$ at M1 can be mostly attributed the kinetic temperature effect only, the oscillation at M5 is also influenced by seasonal changes in gas solubility and methane flux to the SMTZ.

A common procedure for balancing mass fluxes in aquatic sediments relies on using measured solute concentration profiles to derive diffusive transport rates. However, given the seasonal change in rates (Fig. 3), this approach must be treated with caution. To illustrate this point in more detail, Figure 4 shows the dependency of the maximum local 


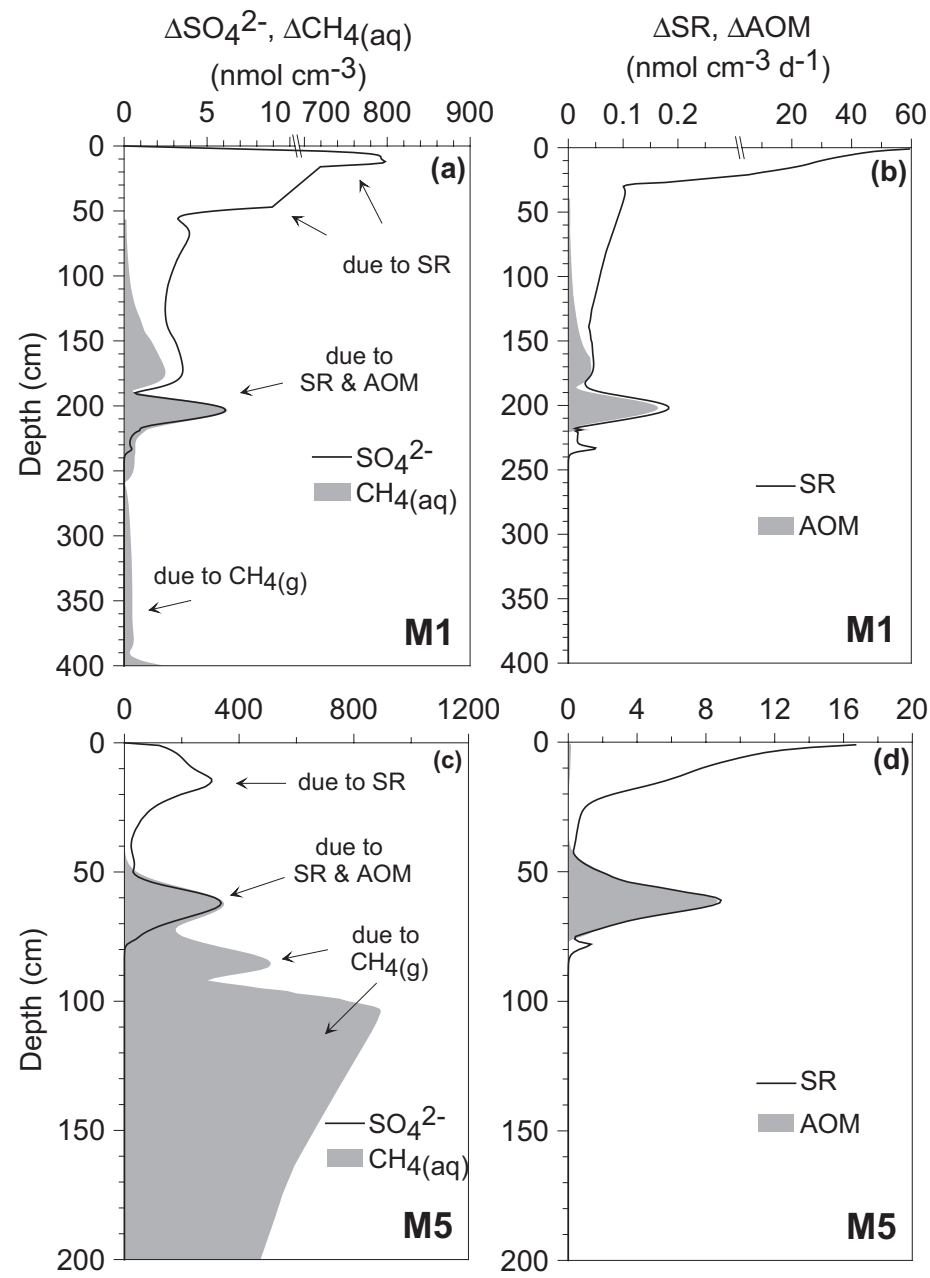

$\triangle \mathrm{SR}, \triangle \mathrm{AOM}$

$\left(\mathrm{nmol} \mathrm{cm} \mathrm{cm}^{-3} \mathrm{~d}^{-1}\right)$

Figure 3. (a) Maximum annual change in $\mathrm{SO}_{4}^{2-}\left(\Delta \mathrm{SO}_{4}^{2-}\right.$, line $)$ and $\mathrm{CH}_{4(\mathrm{aq})}\left(\Delta \mathrm{CH}_{4(\mathrm{aq})}\right.$, shaded) concentrations at M1. (b) Maximum annual change in sulfate reduction ( $\Delta \mathrm{SR}$, line) and AOM rate ( $\triangle \mathrm{AOM}$, shaded) at M1. (c) as (a) for M5, and (d) as (b) for M5.

AOM rate on the temperature at $z_{S M T Z}\left(T_{S M T Z}\right)$. The rate of AOM is the product of $v_{\max }$, which depends on $T$ through the Arrhenius term $f(T)$ (Eq. 6), and the dimensionless kinetic $\left(F_{K}\right)$ and thermodynamic $\left(F_{T}\right)$ factors, which are shown individually in the insets (Fig. $4 \mathrm{a}, \mathrm{b})$. The AOM rate increases from a minimum in spring to a maximum in fall at M1 and summer at M5. However, the seasonal evolution of the AOM rate at $z_{S M T Z}$ is not a simple response to the local temperature and a hysteretic effect occurs, with a greater vertical broadness of the loop in summer/fall than winter/spring. Thus, similar to the relationship between $T_{S W I}$ and $T_{S M T Z}$ (Fig. 2b,c), two possible rates are possible for each temperature, 


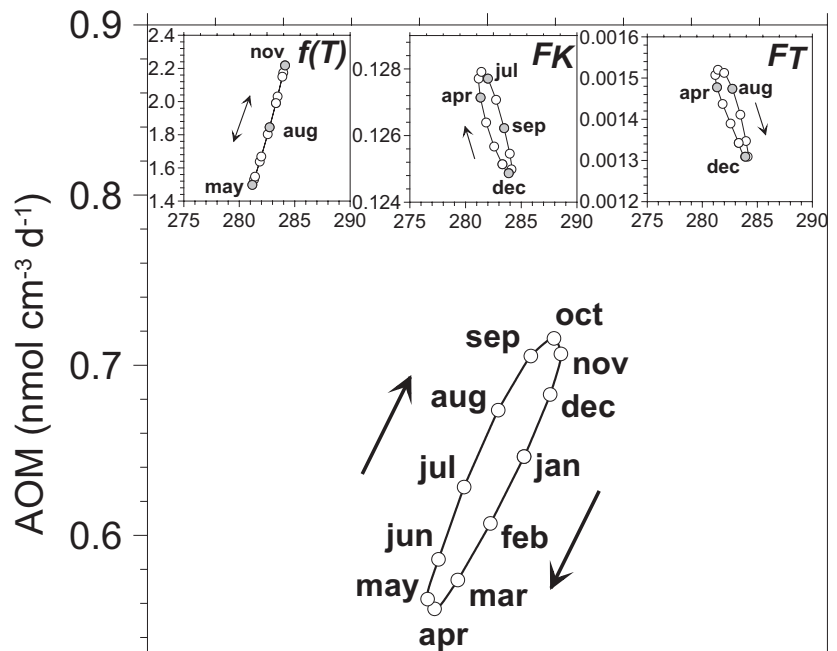

(a) M1

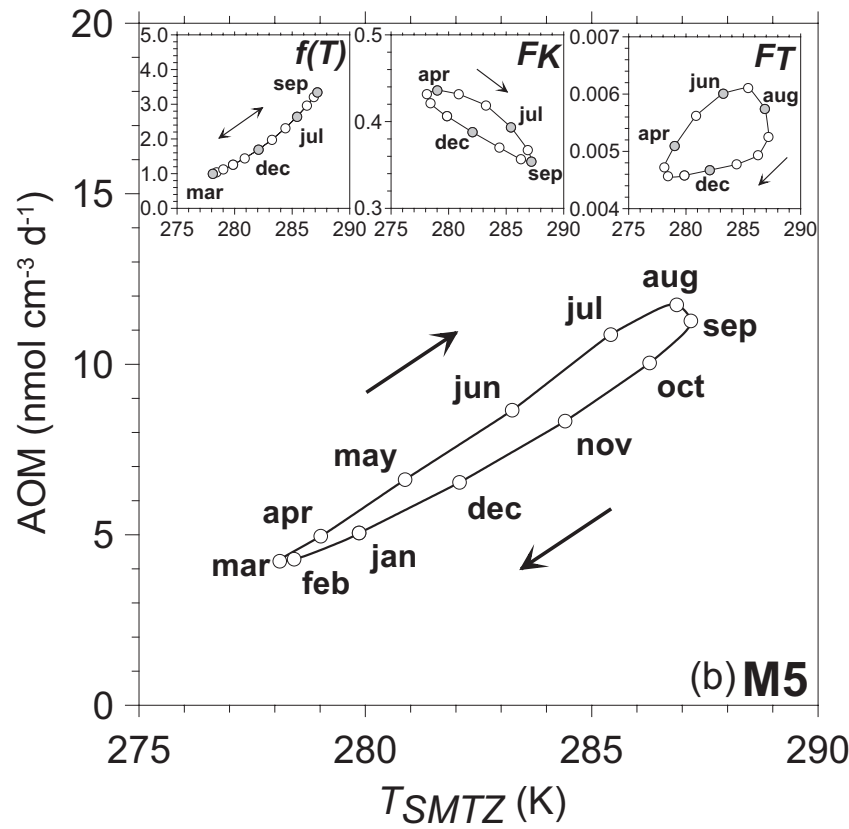

Figure 4. (a) Annual evolution of the local AOM rate versus temperature $\left(T_{S M T Z}\right)$ at the depth of the SMTZ for M1. The inset plots show the (dimensionless) variation in $f(T)$, kinetic drive $\left(F_{K}\right)$ and thermodynamic drive $\left(F_{T}\right)$ for AOM as a function of $T_{S M T Z \text {. }}$ (b) as (a) for M5. 

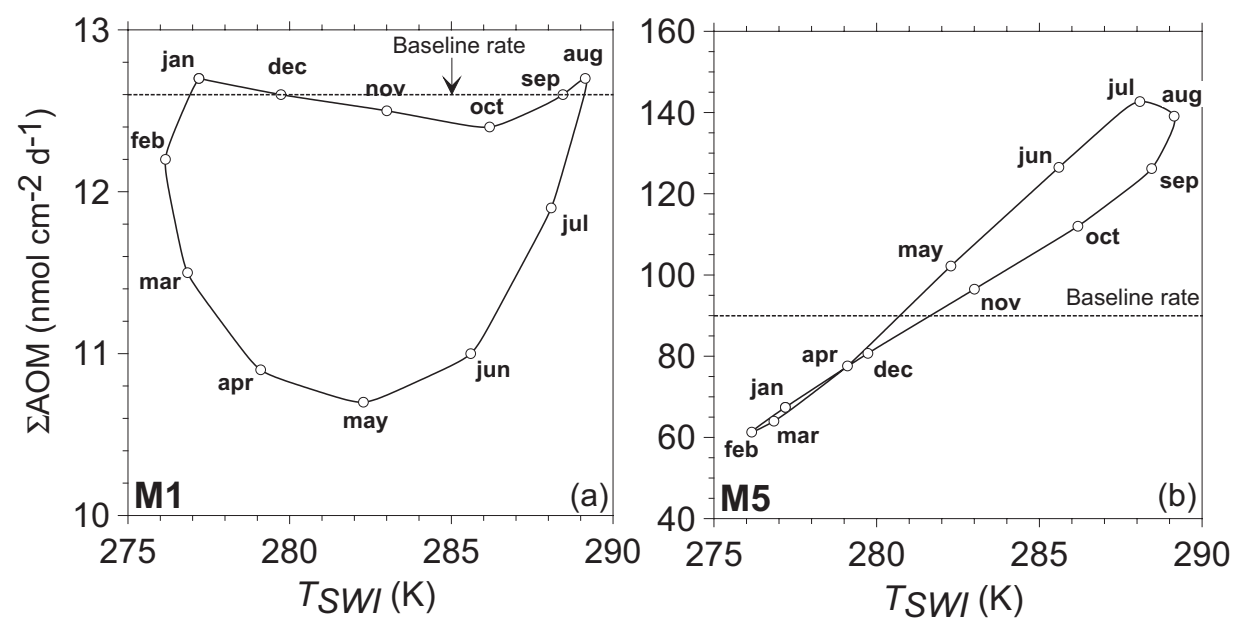

Figure 5. (a) Annual evolution of the depth-integrated AOM rate ( $\Sigma \mathrm{AOM})$ versus $T$ at the sediment-water interface $\left(T_{S W I}\right)$ at M1. The dashed horizontal line corresponds to the baseline simulation rate (Table 1). (b) as (a) for M5.

depending on the season. However, this is not the same Lissajous behavior as observed in Figure $2 \mathrm{c}, \mathrm{d}$ because here the AOM is plotted against the local temperature, $T_{S M T Z}$. The overall range of rate values observed over one year is determined by the $f(T)$ term since, relative to the other factors, this term has the largest range of variation. The hysteresis, on the other hand, arises from the combined effect of the $F_{T}$ and $F_{K}$ terms. Since $F_{T}$ and $F_{K}$ depend on chemical concentrations as well as temperature, it can be hypothesized that the time lags in the rates of production, consumption and diffusive transport of solutes are responsible for the hysteresis. It is unlikely that this hypothesis could be substantiated from direct observation because of the small-scale heterogeneity of natural sediments and analytical uncertainty.

Figure 5 shows the seasonal evolution of depth integrated AOM rates as a function of the bottom water temperature $\left(T_{S W I}\right)$, a parameter routinely measured in the field. Because $T_{S W I}$ is non-linearly related to $T_{S M T Z}$, the $\Sigma \mathrm{AOM}$ rate evolves with $T_{S W I}$ in a non-intuitive manner. Again, the model predicts significant differences in $\Sigma A O M$ rate for identical $T_{S W I}$ from spring to fall. For example, at $287 \mathrm{~K}$, the $\Sigma \mathrm{AOM}$ rate at M5 equals either $130 \mathrm{nmol}$ $\mathrm{cm}^{2} \mathrm{~d}^{-1}$ in fall or $150 \mathrm{nmol} \mathrm{cm} \mathrm{d}^{-1}$ in summer. Moreover, by comparison to the baseline $\sum \mathrm{AOM}$ rate (dashed horizontal line), the model shows that there is a very strong prospect for erroneous methane budget calculations if $\Sigma A O M$ rates pertaining to a single time event are scaled up to yearly time scales. This is especially true for M5 which experiences a larger seasonal range in $T$. Additionally, only two values are predicted for each $T_{S W I}$ here because of the regular sinusoidal forcing imposed in the model. Yet, considering the natural fluctuations in $T_{S W I}$ in the field and the high thermal diffusivity, multiple AOM rate values for the same $T_{S W I}$ may be expected. 


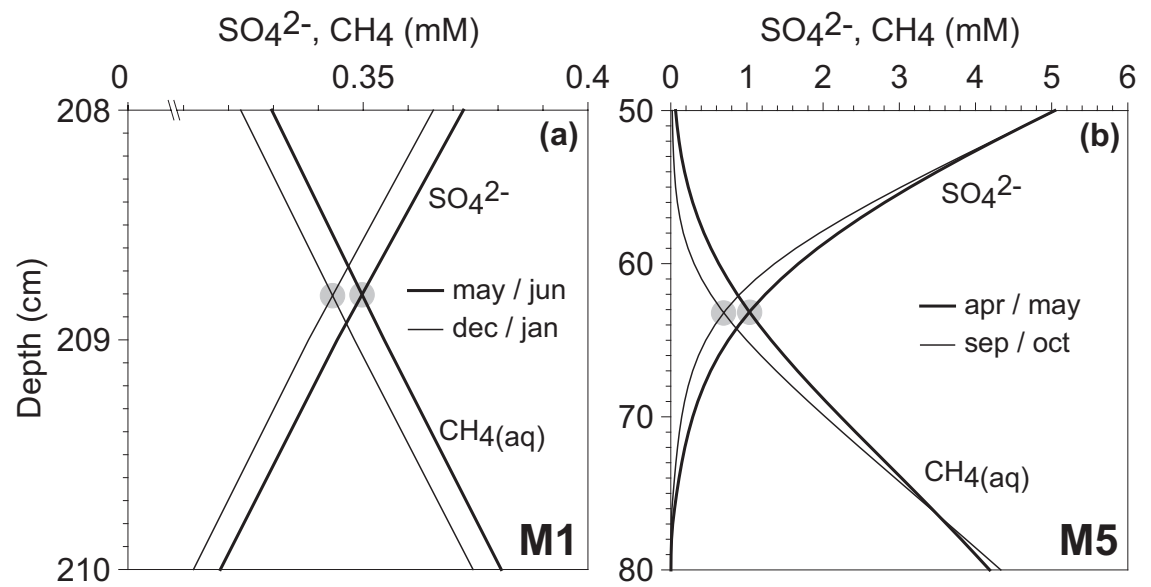

Figure 6. (a) Maximum and minimum modeled concentration profiles of $\mathrm{SO}_{4}^{2-}$ and $\mathrm{CH}_{4(\mathrm{aq})}$ in the SMTZ at M1. The grey points highlight the depth of equimolar $\mathrm{SO}_{4}^{2-}$ and $\mathrm{CH}_{4(\mathrm{aq})}$ concentrations. (b) as (a) for M5. Note the difference depth and concentration scales.

iii. Seasonal displacement of the SMTZ depth $\left(z_{S M T Z}\right)$. Figure 6 shows that $\mathrm{SO}_{4}^{2-}$ penetration varies during the course of one year, with a maximum displacement of 2-3 cm at M5 and $<1 \mathrm{~cm}$ at M1. The changes in $z_{S M T Z}$ are thus much smaller than those of the experimental observations (dashed lines in Fig. 1a,f). Larger seasonal changes in measured sulfate penetration have also been reported at Cape Lookout Bight $(20 \mathrm{~cm}$, Klump and Martens, 1989; Alperin et al., 1994), Eckernförde Bay (10 cm, Treude et al., 2005) and Long Island Sound $\left(15 \mathrm{~cm}\right.$, Westrich and Berner, 1984). The shift in modeled $z_{S M T Z}$ remains limited because, even though the maximum seasonal changes in concentrations and rates are relatively large (Fig. 3), the turnover time of $\mathrm{SO}_{4}^{2-}$ and $\mathrm{CH}_{4(\mathrm{aq})}$ at any given moment in the SMTZ is long $\left(t_{t}=0.5-2\right.$ years). This allows sufficient time for $\mathrm{SO}_{4}{ }^{2-}$ and $\mathrm{CH}_{4(\mathrm{aq})}$ to diffuse over a significantly longer distance $\left(\left(4 . t_{t} \cdot D_{S} / \pi\right)_{1 / 2}^{12} \sim 15 \mathrm{~cm}\right)$ and replenish the relatively small fraction of $\mathrm{SO}_{4}^{2-}$ and $\mathrm{CH}_{4(\mathrm{aq})}$ removed from the porewater by microbial activity. In the following discussion, we explore the mismatch between the modeled and observed $z_{S M T Z}$.

It could be argued that the model underestimates the microbial temperature effect. The microbial response to temperature $\left(f(T)\right.$, Eq. 6) employs a fixed $Q_{10}$ value of 3.8 for terminal metabolism and 2.0 for hydrolysis and fermentation, which implicitly assumes that the activation energy $\left(E_{\mathrm{a}}\right)$ of the rate remains constant. However, Westrich and Berner (1988) reported an inverse relationship between $E_{\mathrm{a}}$ and the SR rate with sediment depth. This was interpreted as the effect of increasing recalcitrance of organic matter leading to an apparent increase in the $E_{\mathrm{a}}$ (i.e. $Q_{10}$ ) for SR. Crill and Martens (1987) reported similar findings for seasonally depth-integrated SR rates in Cape Lookout Bight sediments. We observed that the seasonal variability in $z_{S M T Z}$ was insensitive to temporal and spatial variations in the $Q_{10}$ parameter (data not shown). This can be explained by the strong 
controls by kinetic and bioenergetic factors, which limit the rate of AOM to $<0.1 \%$ of $v_{\max }$ (i.e. $\left.F_{K} \times F_{T}<0.001\right)$. The degree of this limitation appears to be characteristic of substrate-starved microbial networks (Dale et al., 2008), and is too strong for $Q_{10}$ variations to have any real impact on $z_{S M T Z}$. The role of $E_{\mathrm{a}}$ is probably much more important in Cape Lookout Bight, where organic substrates are in abundance and sulfate reducing bacteria at the base of the $\mathrm{SR}$ zone become limited by $\mathrm{SO}_{4}^{2-}$ during much of the year (Alperin et al, 1994). In Aarhus Bay, it appears therefore unlikely that the shifts in $z_{\text {SMTZ }}$ could arise from a direct $T$ effect on microbial activity within the SMTZ or, for the same reason, from short-term time lags in microbial growth (Hoehler et al., 1999).

It is worth considering further the reasons why Cape Lookout Bight and Eckernförde Bay display relatively large seasonal variations in the depth of $\mathrm{SO}_{4}{ }^{2-}$ penetration. The sediment geochemistry at these sites is generally comparable to Aarhus Bay, with free methane gas formation below the SR zone and large fluctuations in $T_{S W I}$. However, sediment accumulation rates in these systems are relatively high $\left(10 \mathrm{~cm} \mathrm{y}^{-1}\right.$ and $1 \mathrm{~cm} \mathrm{y}^{-1}$, respectively), and bioturbation is limited to the upper 1-2 cm or even absent (Martens et al., 1998; Nittrouer et al., 1998). This means that $\mathrm{SO}_{4}^{2-}$ input in the deeper sediment layers occurs only by burial and diffusion across the sediment water interface plus, to a lesser extent, oxidation of dissolved sulfide in the surface sediment (Chanton et al., 1987). Consequently, high summer SR rates coupled to LMW-DOC production will more rapidly deplete the $\mathrm{SO}_{4}^{2-}$ pool during summer than during other periods of the year (Crill and Martens, 1987; Alperin et al., 1994; Treude et al., 2005). For instance, Alperin et al. (1994) showed that $\mathrm{SO}_{4}^{2-}$ diffuses to greater depths only at the end of the fall when production of LMW-DOC slows down. In contrast, bioturbation and especially bioirrigation in Aarhus Bay continually replenish the $\mathrm{SO}_{4}^{2-}$ pool and buffer the effect of seasonal SR variation, thus partially attenuating the role of $T$ on pore water chemistry (Fossing et al., 2004).

Irrigation intensity may vary significantly at the same sampling location (Heilskov et al., 2006) and the magnitude and timing of this process do not necessarily follow a straightforward seasonal pattern (Aller and Aller, 1992; Schlüter et al., 2000; Forster et al., 2003). Studies of North Sea sediments by Forster et al. (2003) showed that the seasonal variability in the irrigation rate constant $\left(\alpha_{0}\right)$ was statistically comparable to the variability among adjacent cores sampled simultaneously, and they attributed this anomaly to spatial heterogeneity of faunal abundance. These authors were further able to show that the pumping action of burrowing infauna increased under hypoxic conditions $\left(\mathrm{O}_{2} \sim 50 \mu \mathrm{M}\right)$ as the animals became oxygen stressed. Although no $\mathrm{O}_{2}$ data were measured during our sampling in Aarhus Bay, bottom water $\mathrm{O}_{2}$ concentrations of $50 \mu \mathrm{M}$ appear typical for the end of summer (Thamdrup et al., 1994; Glud et al., 2003). Without the necessary data, we are unable to determine precisely the quantitative significance of seasonal changes in bioirrigation with the model. Intuitively, though, and considering the time scales of $\mathrm{SO}_{4}^{2-}$ diffusion, one can expect seasonal fluctuations in bioirrigation to have little impact on the downward flux of $\mathrm{SO}_{4}^{2-}$ and $z_{S M T Z}$. The time required for $\mathrm{SO}_{4}^{2-}$ to diffuse from below the irrigated depth $(15 \mathrm{~cm})$ to the SMTZ is about $250 \mathrm{y}$ at M1 and $18 \mathrm{y}$ at M5. Intra-annual 
Table 4. Depth of the SMTZ ( $z_{S M T Z}$ ) following a $\pm 25 \%$ change in bioirrigation intensity (Bio), the gas diffusion coefficient $\left(D_{\mathrm{CH} 4(\mathrm{~g})}\right)$ and gas concentration at the lower boundary $\left(\mathrm{C}_{\left.\mathrm{L}-\mathrm{CH}_{4(\mathrm{~g})}\right)}\right.$ relative to the apparent seasonal changes in the measured chemical data. The simulations were performed at steady state.

$\begin{array}{ccccc} & \text { Data } & \pm 25 \% \text { Bio } & \pm 25 \% D_{C H 4(g)} & \pm 25 \% C_{L-C H 4(g)} \\ \text { M1 } & 221 \pm 40 & 221 \pm 18 & 221 \pm 2 & 221 \pm 34 \\ \text { M5 } & 63 \pm 8 & 63 \pm 5 & 63 \pm 10 & 63 \pm 9\end{array}$

variations in $\mathrm{SO}_{4}^{2-}$ concentration due to bioturbation and bioirrigation will thus be dampened by diffusion and tend not to be preserved in the deeper portion of the solute profiles. Periodicities in sea floor bioirrigation on multi-decadal time scales will be required to engender cyclicity in $z_{S M T Z}$ (Lasaga and Holland, 1976; Burdige, 2006).

Pore water exchange through bioirrigation is a much more complex process than suggested by the 1-D non-local function assumed in the model (Table 3). Even though this approach provides a valuable means of extracting quantitative information on squeezed pore water samples (Berg et al., 1998), the natural variation in burrow geometry, size and density leads to particularly complex solute exchange process (Aller and Aller, 1992; Meile et al., 2005; Meysman et al., 2006). Furthermore, the density of macro-fauna in Aarhus Bay is highly variable (2800 $\pm 700 \mathrm{~m}^{2}$, Glud et al., 2003), which makes local heterogeneity in bioirrigation rates very likely. We tested the sensitivity of $z_{S M T Z}$ to the bioirrigation intensity by applying the same relative standard deviation to the maximum bioirrigation rate constant $\left(\alpha_{0}\right)$ and irrigation depth $\left(\beta_{I}\right)$ at each site and re-running the baseline simulation. With enhanced $\mathrm{SO}_{4}^{2-}$ exchange, $z_{S M T Z}$ showed a total displacement of $36 \mathrm{~cm}$ at $\mathrm{M} 1$ and $10 \mathrm{~cm}$ at M5 (Table 4), which is more comparable to the variability observed in the field data $(80 \mathrm{~cm}$ at M1 and $16 \mathrm{~cm}$ at M5). The natural spatial heterogeneity in irrigation could, in theory, account for the apparent seasonal variability in $z_{S M T Z}$, but this requires that the same spatial differences in bioirrigation (faunal abundance) should be maintained within the $50 \times 50 \mathrm{~m}$ sampling area on the time-scale of $\mathrm{SO}_{4}^{2-}$ diffusion to the SMTZ (up to $\sim 250$ y at M1). Because this seems improbable, we can confidently eliminate a significant effect of bioirrigation intensity on either intra- and inter-annual variations on sulfate penetration at M1 or M5.

Therefore, the model suggests that the effects of seasonal or long-term variability in forcing at the sediment surface are not sufficient to account for the observed seasonal shifts in $z_{S M T Z}$ at each sampling station. Consequently, to reconcile model and analytical data, the changes in $z_{S M T Z}$ must be driven by processes originating from below the SMTZ, i.e. the upward transport of methane gas. The amount of $\mathrm{CH}_{4(\mathrm{~g})}$ transported upwards depends on the specified lower boundary gas volume ( $3 \%$, Table 3 ) and the apparent diffusion coefficient $\left(D_{C H 4(g)}\right)$, which is an order of magnitude higher than the molecular diffusion coefficient for $\mathrm{CH}_{4(\mathrm{aq})}$. Even so, we observed that a strong seasonal $T$-dependency of $D_{C H 4(g)}$ as well as the rates of gas formation and dissolution $\left(k_{G F}, k_{\text {diss }}\right)$ always had minor effect on $z_{S M T Z}$ (data not shown). On the other hand, the change in $z_{S M T Z}$ due to a $\pm 25 \%$ 
change in $D_{C H 4(g)}$ and the boundary gas volume showed very different results under steady state conditions (Table 4 ). The $\pm 25 \%$ variability is not intended to embrace the confidence interval of the parameterization, but rather illustrate the sensitivity of $z_{S M T Z}$ to $D_{C H 4(g)}$ and the boundary gas volume. The results show that $z_{S M T Z}$ is sensitive to $D_{C H 4(g)}$ at M5, but not at M1 because of the lower $D_{C H 4(g)}$ used to model the data at this site $\left(1400 \mathrm{~cm}^{2} \mathrm{y}^{-1}\right)$. The imposed gas volume has much more impact on $z_{S M T Z}$ at $\mathrm{M} 1$, which undergoes a maximum displacement of $\pm 34 \mathrm{~cm}$, and also for M5, which shows a variation of $\pm 9 \mathrm{~cm}$. We thus conclude that different vertical gas transport fluxes within the same 50x50 m sampling area account for most of the apparent seasonal displacement of the SMTZ. However, without measured gas volume data, we are presently unable to identify the relative importance of $D_{C H 4(g)}$ versus gas occupancy. The way which gas is transported in natural sediments is not fully understood, but the high capillary forces within consolidated sediments are likely to limit migration of $z_{S M T Z}$ through fracturing (Sills and Wheeler, 1992; Boudreau et al., 2005). Our results support the findings of Laier and Jensen (2007), who postulated that enhanced gas transport occurs throughout the Baltic Sea region, and which could reflect the contrasting lithology of the Holocene marine units.

\section{Conclusions}

A transient reactive-transport model (RTM) of sulfate and methane cycling in shallow marine sediments of Aarhus Bay has been developed to study the seasonal dynamics imposed by variations in temperature and organic carbon deposition fluxes. The vertical propagation of temperature through the sediment core was explicitly accounted for in the RTM by the heat equation. The model implementation was verified by comparing the simulated vertical solute profiles and sulfate-reduction rates against field data collected in December 2004.

Model results reveal that the transient behavior imposed by the fluctuating temperature deeply influenced the dynamics of the sulfate-methane transition zone (SMTZ). A significant hysteresis-type behavior between local temperature and rates of anaerobic oxidation of methane (AOM) was obtained. Time lags due to the propagation of heat from the sediment surface down to the SMTZ add further complexity if AOM rates are investigated against temperature at the sediment-water interface - a measurable quantity. Therefore, the large seasonal evolution in biogeochemical process rates cannot be constrained from the knowledge of the seasonal evolution of temperature in the overlying water alone.

The large variations in reaction rates were barely recorded in the time evolution of the solute concentrations due to smearing by molecular diffusion. Comparison between modeled and measured profiles revealed a complete failure of the model to simulate the apparently large seasonal shifts in the depth of the SMTZ observed in cores sampled repeatedly from the same $50 \times 50 \mathrm{~m}$ sampling stations over 2 years. The most likely explanation is that the SMTZ does not exhibit seasonal fluctuations at all, but is instead sensitive to the spatial heterogeneity of gas transport and, to a lesser extent, pore water 
irrigation rates. Consequently, methane budgets of Aarhus Bay sediments must not only account for the seasonal change in AOM rates due to temperature but also for the natural variability in the gas depth and faunal activity in the surface sediments. This means that multiple sediment core extractions will be required to calculate system-scale chemical budgets of Aarhus Bay sediments within an acceptable standard deviation.

Acknowledgments. We would like to thank Captain P. Nathansen of StF 57 Henry for skillful gravity coring, Jørn Bo Jensen for information on the seismic data, Tanja Quottrup for assistance during sampling and analyses, and Vincent Mastalerz for assisting with the methane solubility calculations. We are also grateful to DHI, Water \& Environment (Denmark) for providing the bottom water temperature data. AWD and DRA were financially supported by Netherlands Organization for Scientific Research (NWO, VIDI grant no. 864.05.007 and no. 813.02.008 and, respectively) and the European Commission (METROL project EVK3- CT-2002-00080).

\section{REFERENCES}

Abegg, F. and A. L. Anderson. 1997. The acoustic turbid layer in muddy sediments of Eckernfoerde Bay, Western Baltic: methane concentration, saturation and bubble characteristics. Mar. Geol., 137, 137-147.

Aller, R. C. and J. Y. Aller. 1992. Meiofauna and solute transport in marine muds. Limnol. Oceanogr., 37, 1018-1033.

Alperin, M. J., D. B. Albert and C. S. Martens. 1994. Seasonal variations in production and consumption rates of dissolved organic carbon in an organic-rich sediment. Geochim. Cosmochim. Acta, 58, 4909-4930.

Anderson, A. L., F. Abegg, J. A. Hawkins, M. E. Duncan, and A, P. Lyons. 1998. Bubble populations and acoustic interaction with the gassy floor of Eckernförde Bay. Cont. Shelf Res., 18, 1807-1838.

Berg, P., N. Risgaard-Petersen and S. Rysgaard. 1998. Interpretation of measured concentration profiles in sediment pore water. Limnol. Oceanogr., 43, 1500-1510.

Berner, R. A. 1980. Early Diagenesis: A Theoretical Approach, Princeton University Press. 241 pp. Boetius, A., K. Ravenschlag, C. J. Schubert, D. Rickert, F. Widdel, A. Gieseke, R. Amann, B. B. Jørgensen, U. Witte and O. Pfannkuche. 2000. A marine microbial consortium apparently mediating anaerobic oxidation of methane. Nature, 407, 623-626.

Boudreau, B. P. 1997. Diagenetic Models and Their Implementation: Modelling Transport and Reactions in Aquatic Sediments, Springer-Verlag, 414 pp.

Boudreau, B. P., C. Algar, B. D. Johnson, I. Croudace, A. Reed, Y. Furukawa, K. M. Dorgan, P. A. Jumars, A. S. Grader and B. S Gardiner. 2005. Bubble growth and rise in soft sediments. Geology, 33,517-520.

Brüchert, V. and C. Arnosti. 2003. Anaerobic carbon transformation: experimental studies with flow-through cells. Mar. Chem., 80, 171-183.

Burdige, D. J. 2006. Geochemistry of Marine Sediments. Princeton University Press, 609 pp.

Chanton, J. P., C. S. Martens and M. B. Goldhaber. 1987. Biogeochemical cycling in an organic-rich coastal marine basin. 7. Sulfur mass balance, oxygen uptake and sulfide retention. Geochim. Cosmochim. Acta, 51, 1187-1199.

Crill, P. M. and C. S. Martens. 1987. Biogeochemical cycling in an organic-rich coastal marine basin. 6. Temporal and spatial variations in sulfate reduction rates. Geochim. Cosmochim. Acta, 51, $\underline{1175-1186 .}$

Dale, A. W., P. Regnier, N. Knab, B. B. Jørgensen and P. Van Cappellen. 2008. Anaerobic oxidation of methane (AOM) in marine sediments from the Skagerrak (Denmark): II. Reaction-transport modeling. Geochim. Cosmochim. Acta, doi: 10.1016/j.gca.2007.11.039. 
Dale, A. W., P. Regnier and P. Van Cappellen. 2006. Bioenergetic controls on anaerobic oxidation of methane (AOM) in coastal marine sediments: A theoretical analysis. Am. J. Sci., 306, 246-294.

Duan, Z., N. Moller, J. Greenberg and J. H. Weare. 1992. The prediction of methane solubility in natural waters to high ionic strength from 0 degrees to 250 degrees and from 200 to 1600 bar. Geochim. Cosmochim. Acta, 56, 1451-1460.

Forster, S., A. Khalili and J. Kitlar. 2003. Variation of nonlocal irrigation in a subtidal benthic community. J. Mar. Res., 61, 335-357.

Fossing, H., P. Berg, B. Thamdrup, S. Rysgaard, H. M. Sørensen and K. Nielsen. 2004. A model set-up for an oxygen and nutrient flux model for Aarhus Bay (Denmark). National Environmental Research Institute (NERI) Technical Report, 483, 68 pp.

Fossing, H., T. G. Ferdelman and P. Berg, 2000. Sulfate reduction and methane oxidation in continental margin sediments influenced by irrigation (South-East Atlantic off Namibia). Geochim. Cosmochim. Acta, 64, 897-910.

Fossing, H. and B. B. Jørgensen. 1989. Measurement of bacterial sulfate reduction in sediments: Evaluation of a single-step chromium reduction method. Biogeochemistry, 8, 205-222.

Glud, R. N., J. K. Gundersen, H. Røy and B. B. Jørgensen. 2003. Seasonal dynamics of benthic $\mathrm{O}_{2}$ uptake in a semienclosed bay: Importance of diffusion and faunal activity. Limnol. Oceanogr., 48 , $1265-1276$.

Hall, P. O. J. and R. C. Aller. 1992. Rapid, small-volume flow-injection analysis for $\mathrm{SCO}_{2}$ and $\mathrm{NH}_{4}{ }^{+}$ in marine and freshwaters. Limnol. Oceanogr., 37, 1113-1118.

Heilskov, A. C., M. Alperin and M. Holmer. 2006. Benthic fauna bio-irrigation effects on nutrient regeneration in fish farm sediments. J. Exp. Mar. Biol. Ecol., 339, 204-225.

Hoehler, T. M., M. J. Alperin, D. B. Albert and C. S. Martens. 1994. Field and laboratory studies of methane oxidation in an anoxic marine sediment - evidence for a methanogen-sulfate reducer consortium. Global Biogeochem. Cy., 8, 451-463.

Hoehler, T. M., C. B. Albert, M. J. Alperin and C. S. Martens. 1999. Acetogenesis from $\mathrm{CO}_{2}$ in an anoxic marine sediment. Limnol. Oceanogr., 44, 662-667.

Jackson, D. R. and M. D. Richardson. 2001. Seasonal temperature gradients within a sandy seafloor: implications for acoustic propagation and scattering, in Acoustical Oceanography, Proceedings of the Institute of Acoustics, T. G. Leighton, G. J. Heald, H. D. Griffiths and G. Griffiths, eds., 23, 361-368.

Jensen J. B. and T. Laier. 2003. Cruise Report-M/S Line Cruise to the Århus Bay. Geological Survey of Denmark and Greenland Report 2003/96.

Jin, Q. and C. M. Bethke. 2005. Predicting the rate of microbial respiration in geochemical environments. Geochim. Cosmochim. Acta, 69, 1133-1143.

Jørgensen, B. B. 1978. A comparison of methods for the quantification of bacterial sulfate reduction in coastal marine sediments. I. Measurement with radiolabel techniques. Geomicrobiol. J., 1, 11-27.

Klump, J. V. and C. S. Martens. 1989. The seasonality of nutrient regeneration in an organic-rich coastal sediment: kinetic modeling of changing pore-water nutrient and sulfate distributions. Limnol. Oceanogr., 34, 559-577.

Koretsky, C. M., P. Van Cappellen, T. J. DiChristina, J. E. Kostka, K. L. Lowe, C. M. Moore, A. N. Roychoudhury and E. Viollier. 2005. Salt marsh pore water geochemistry does not correlate with microbial community structure. Estuar. Coast. Shelf Sci., 62, 233-251.

Laier, T. and J. B. Jensen. 2007. Shallow gas depth-contour map of the Skagerrak-western Baltic Sea region. Geo-Mar. Lett., 27, 127-141.

Lasaga, A. C. and H. D. Holland. 1976. Mathematical aspects of non-steady-state diagenesis. Geochim. Cosmochim. Acta, 40, 257-266.

Martens, C. S., D. B. Albert and M. J. Alperin. 1998. Biogeochemical processes controlling methane 
in gassy coastal sediments - Part 1. A model coupling organic matter flux to gas production, oxidation and transport. Cont. Shelf Res., 18, 1741-1770.

Martens, C. S. and R. A. Berner. 1977. Interstitial water chemistry of anoxic Long Island Sound sediments. 1. Dissolved gases. Limnol. Oceanogr., 22, 10-25.

Matisoff, G. 1980. Time dependent transport in Chesapeake Bay sediments; Part 1, Temperature and chloride. Am. J. Sci., 280, 1-25.

Meile, C., P. Berg, P. Van Cappellen and K. Tuncay. 2005. Solute-specific pore water irrigation: Implications for chemical cycling in early diagenesis. J. Mar. Res., 64, 601-621.

Meysman, F. J. R., O. S. Galaktionov, B. Gribsholt and J. J. Middelburg. 2006. Bioirrigation in permeable sediments: Advective pore-water transport induced by burrow ventilation. Limnol. Oceanogr., 51, 142-156.

Mogollón, J., I. L'Heureux, A. Dale, P. Regnier. 2008. Methane gas-phase dynamics in marine sediments: a model study. Am. J. Sci. (submitted).

Moodley, L., J. J. Middelburg, K. Soetaert, H. T. S. Boschker, P. M. Herman, and C. H. R. Heip. 2005. Similar rapid response to phytodetritus deposition in shallow and deep-sea sediments. J. Mar. Res., 63, 457-469.

Nauhaus, K., T. Treude, A. Boetius and M. Krüger. 2005. Environmental regulation of the anaerobic oxidation of methane: a comparison of ANME-I and ANME-II communities. Environ. Microbiol., 7,98-106.

Nittrouer, C. A., G. R. Lopez, D. Wright, S. J. Bentley, A. F. D’Andrea, C. T. Friedrichs, N. I. Craig and C. K. Sommerfield. 1998. Oceanographic processes and the preservation of sedimentary structure in Eckernförde Bay, Baltic Sea. Cont. Shelf Res., 18, 1689-1714.

Reeburgh, W. S. 1996. "Soft spots" in the global methane budget, in Microbial Growth on C1 Compounds, M. E. Lidstrom and F. R. Tabita, eds., Kluwer Academic Publishers, 334-342.

Schlüter, M., E. Sauter, H. P. Hansen and E. Suess. 2000. Seasonal variations of bioirrigation in coastal sediments: modelling of field data. Geochim. Cosmochim. Acta, 64, 821-834.

Schulz, H. D. 2000. Conceptual models and computer models, in Marine Geochemistry, H. D. Schulz, and M. Zabel, eds., Springer-Verlag, Berlin, 417-442.

Sills, G. C. and S. J. Wheeler. 1992. The significance of gas for offshore operations. Cont. Shelf Res., $12,1239-1250$.

Soetaert, K., P. M. J. Herman, and J. J. Middelburg. 1996. Dynamic response of deep-sea sediments to seasonal variations: A model. Limnol. Oceanogr., 41, 1651-1668.

Thamdrup, B., H. Fossing and B. B Jørgensen. 1994. Manganese, iron and sulfur cycling in a coastal marine sediment, Aarhus Bay, Denmark. Geochim. Cosmochim. Acta, 58, 5115-5129.

Treude, T., M. Krüger, A. Boetius and B. B. Jørgensen. 2005. Environmental control on anaerobic oxidation of methane in the gassy sediments of Eckernförde Bay (German Baltic). Limnol. Oceanogr., 50, 1771-1786.

Weston, N. B. and S. B. Joye. 2005. Temperature-driven decoupling of key phases of organic matter degradation in marine sediments. Proc. Nat. Acad. Sci. USA, 102, 17036-1740.

Westrich, J. T. and R. A. Berner. 1984. The role of sedimentary organic matter in bacterial sulfate reduction: the G-model tested. Limnol. Oceanogr., 29, 236-249.

1988. The effect of temperature on rates of sulfate reduction in marine sediments. Geomicrobiol. J., 6, 99-117.

Woodside, W. and J. H. Messmer. 1961. Thermal conductivity of porous media. I. Unconsolidated sands. J. Appl. Phys., 32, 1688-1699. 